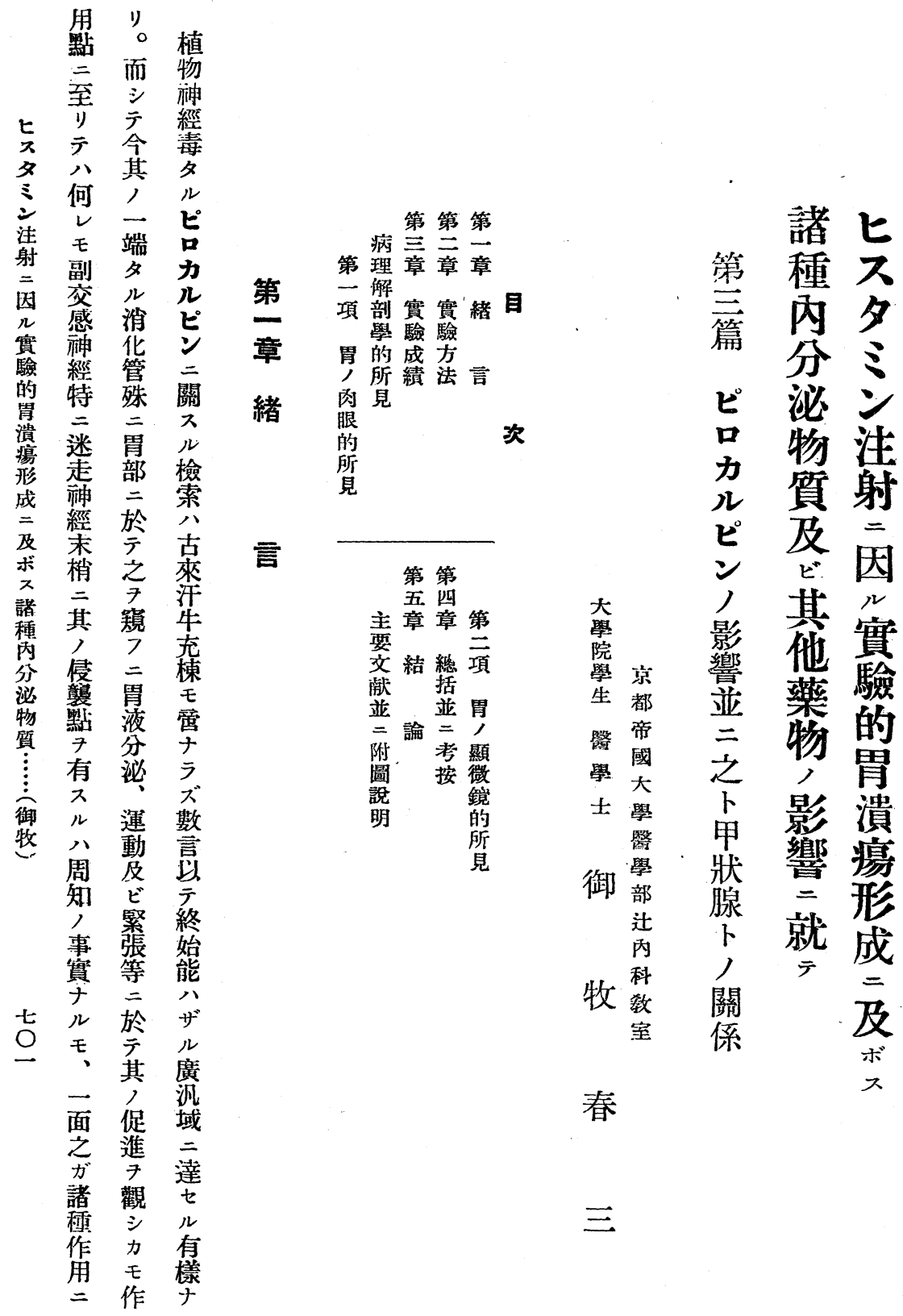




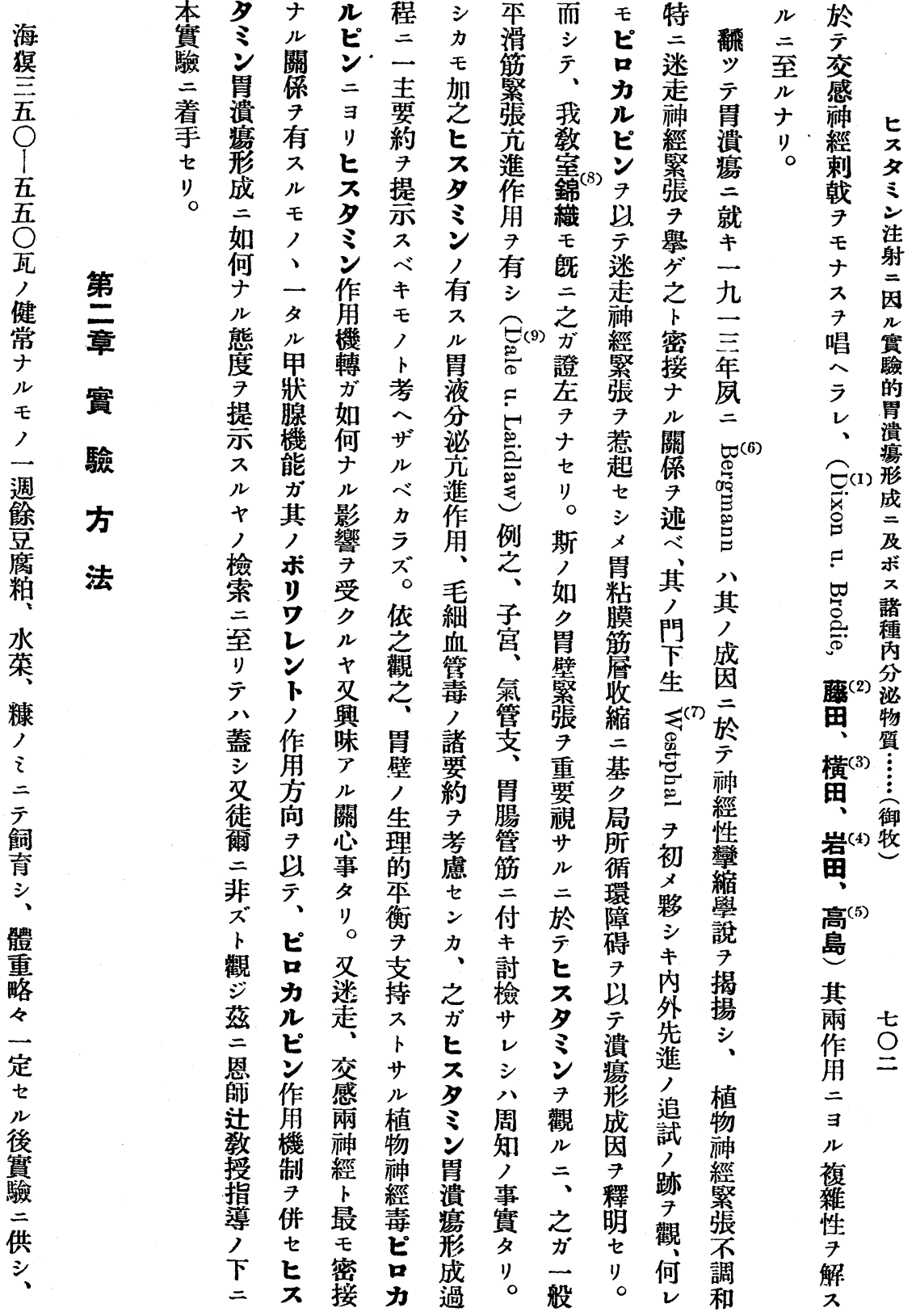




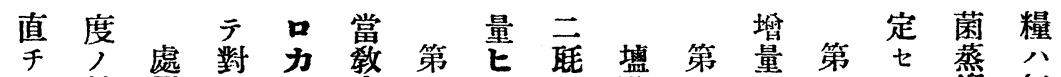

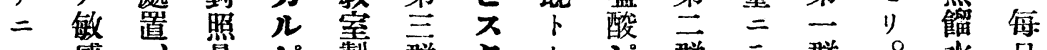

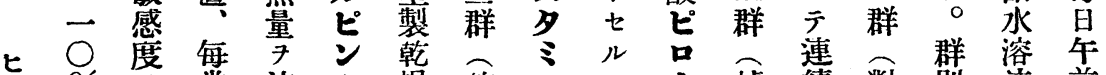

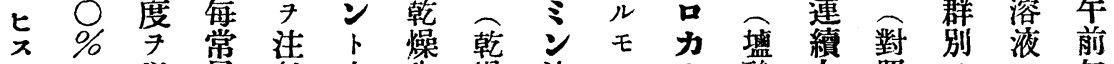
夕> 以最射夫牛燥注, 几酸壬照子年

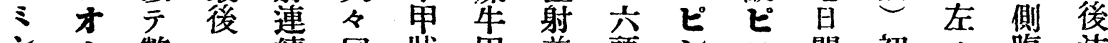
洼儿檠, 續同牀早前頭シ品間初, 腹注

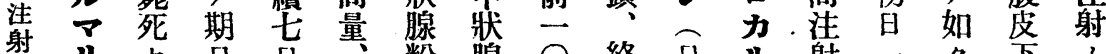
$=$ ○ 七 因ンシ、間同末粉 1 始本ピシ頭分一中

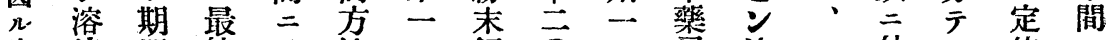
惯 液 間終及法日飼○日局注一付り位一 驗内内注 ブ 一食分二法射旦每。置定 的固自射六施頭 後

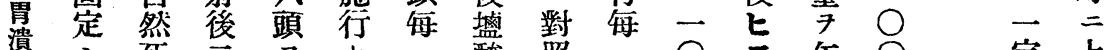
型 シ 死數立 成次子四ナ四○吕洼 00 午體度糧 及 ホル七至 二重ピ 位重鮮射回立洼定

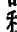

眔

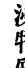

物立隼桨

算示公

儿避

寉示号品

跑硬少品

花 $\times$

脫致 几

水死絫

、永磨

展死

士 王的

学染譄

$1=$

离离旨

包的力

濹盟

後見占宁給

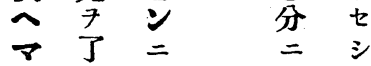

下强

融

頭・注反! 囷

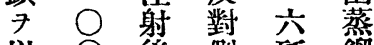

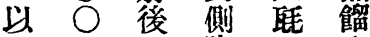

厂龙腹水

之四六些

三瓦多七几液

克宛罗玉君

嗰旨滋運四筸

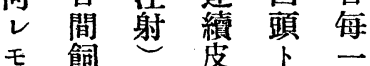

ヒ会全

唯洼。

力第射一再

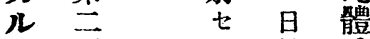

ヒ群少量重

, $\Rightarrow$

洼 六

射頭

後 並

○西

I 頭

产
品何品

彗王铎

先富第

行等

等見

照
榇後
分 五

分注

ル

六始體り。

頭 、變 ヒ

寻一华

t

ル念

繁

O

望

體

重

$\dot{0}$

五

瑤

差

級

數

的
藥 名

量 $\widehat{\sigma}$

影

几 會

7 街

慗

每,

常 新

碾 鮮

定

時 ○

二 倍 


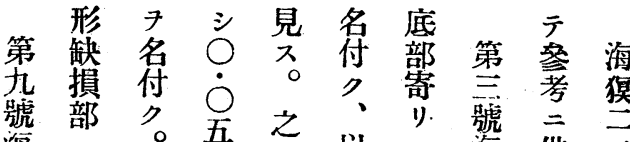

號 部 。 五 之 以

猽 少 $\bigcirc$ り

第認之立更之惩第文個

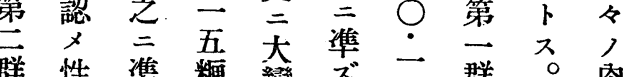

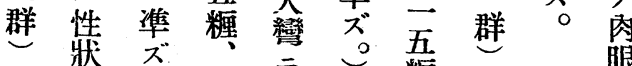

胃忠棈接境粧胃的

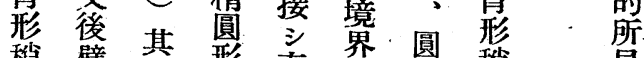

稍 壁 其 形 直 界 圓 稍

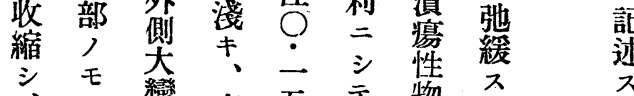

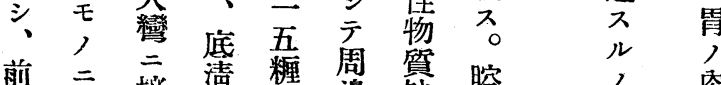

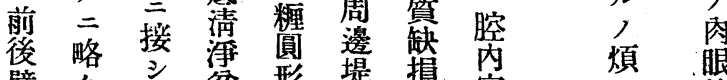

壁々 シ 貧形题損容方的

二同直血潰防 万族

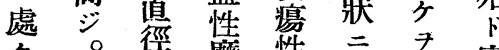

紫。徑痵性㘂認空

垃 $\div$ 性罂隆台 三

帕糎物筷 シ

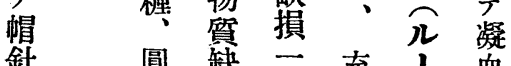

鎮 圓 缺方 充 は。血

笑 缺 損 血 ペ

人損ヶリ少

モ 一 7 ○ 等 リ ズ

見少認性度略唯

二 體惡卡認粘 粘

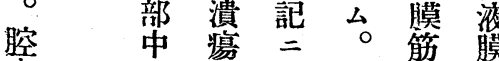

內 英性略底愿中

凝 大物名清及等

血彎質同淨

ナ 二缺ジを子

キ 接 損 。 依容

粘辛沓後壁稍

椆徑 淺 底々 達 前

$ナ \bigcirc$ 在 部淡七壁

ル

粘榞而彎色

膜一圆, 接窥 7 央

避所

ケ、見

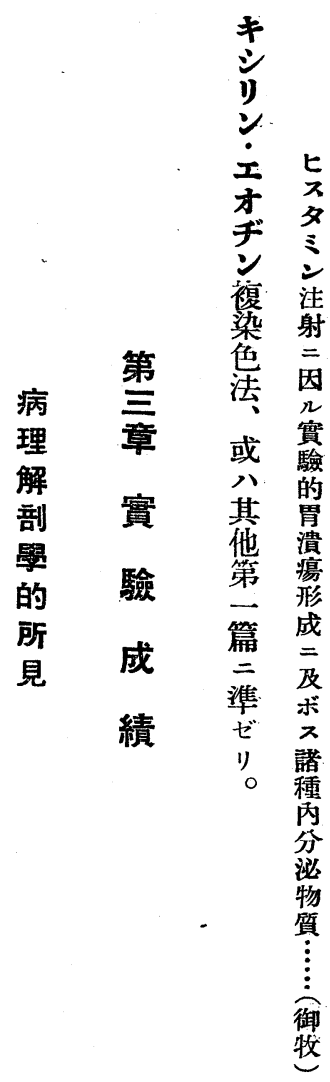

死
表
的
年
モ
フ
記
シ

垈
表
的
E
,
7
記
シ

次

$=$

群

志

分 


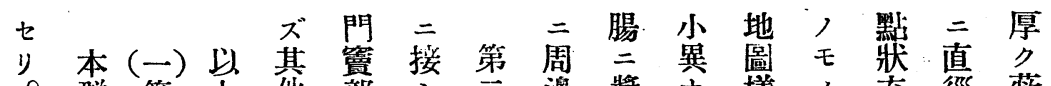

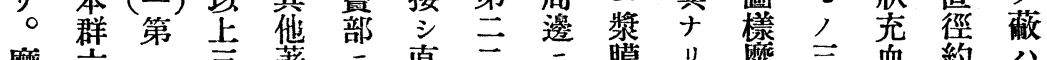

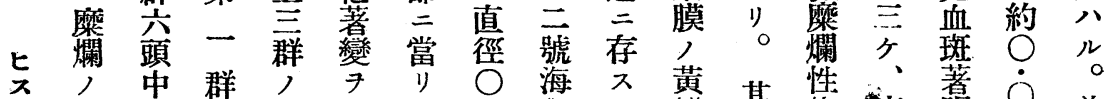

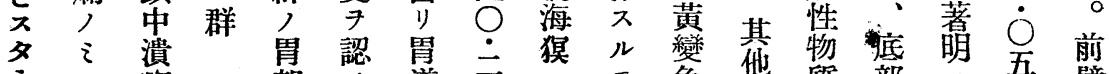

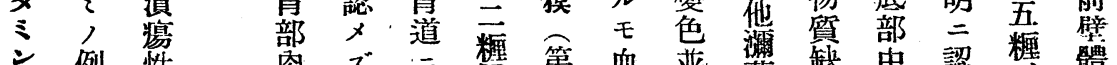
菭例性 怼

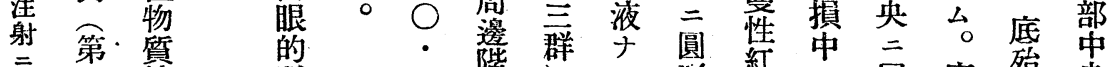

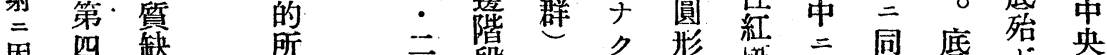

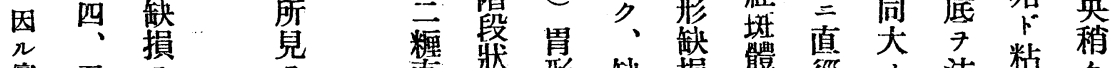

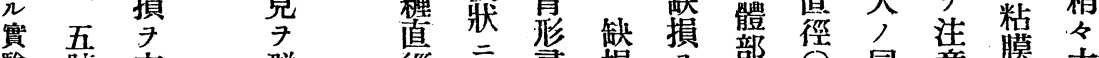
的 大 別

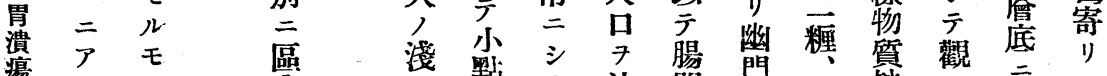

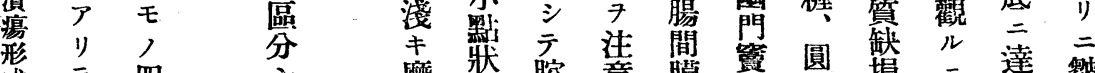

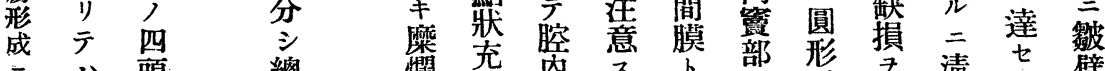

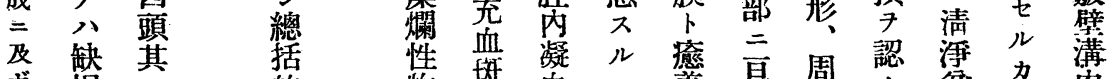

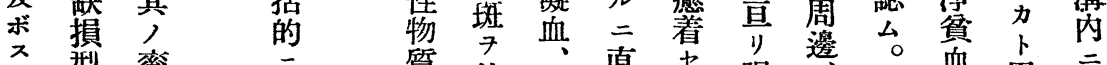
硣型率 質件、直七强遥。血思二

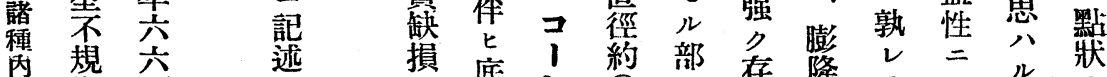
分則 \% 提 七 底

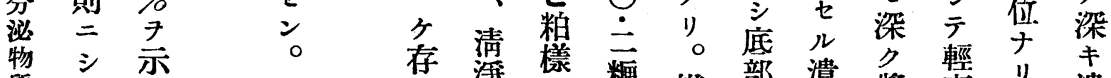

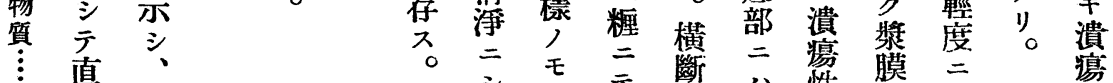

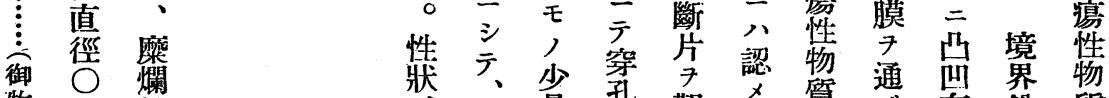
牧 性 、

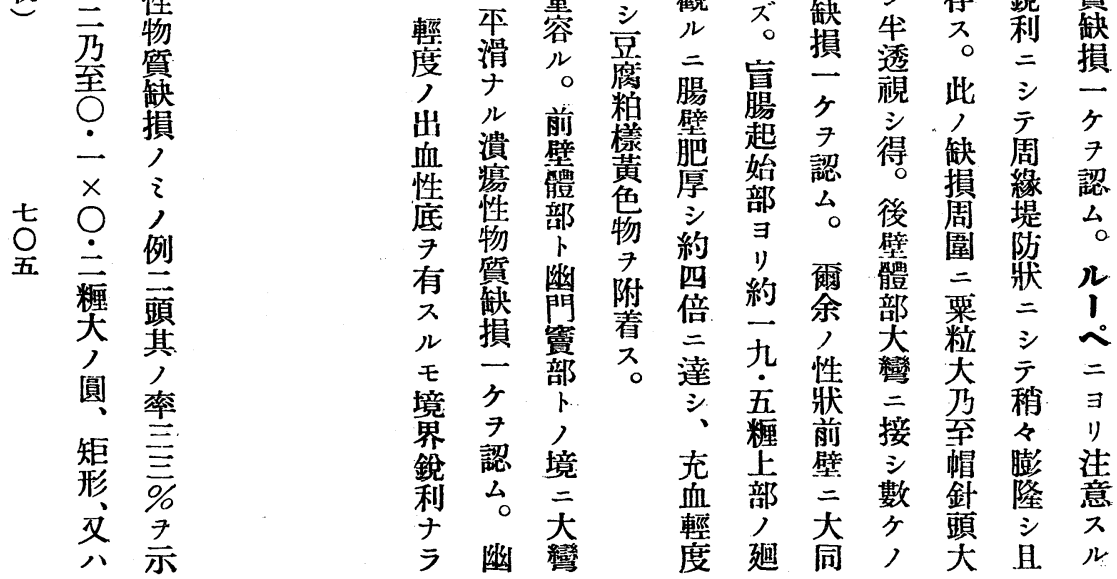




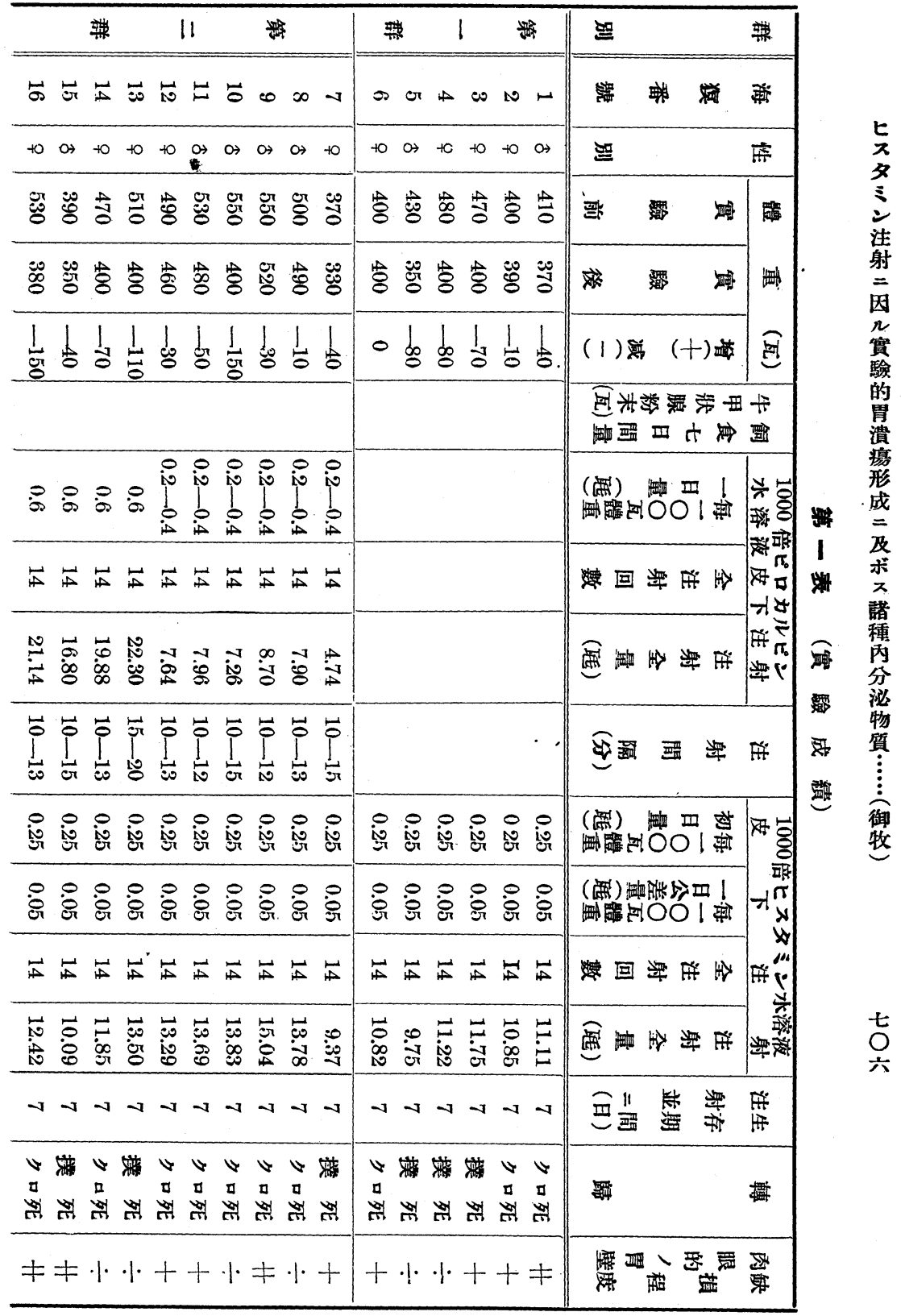




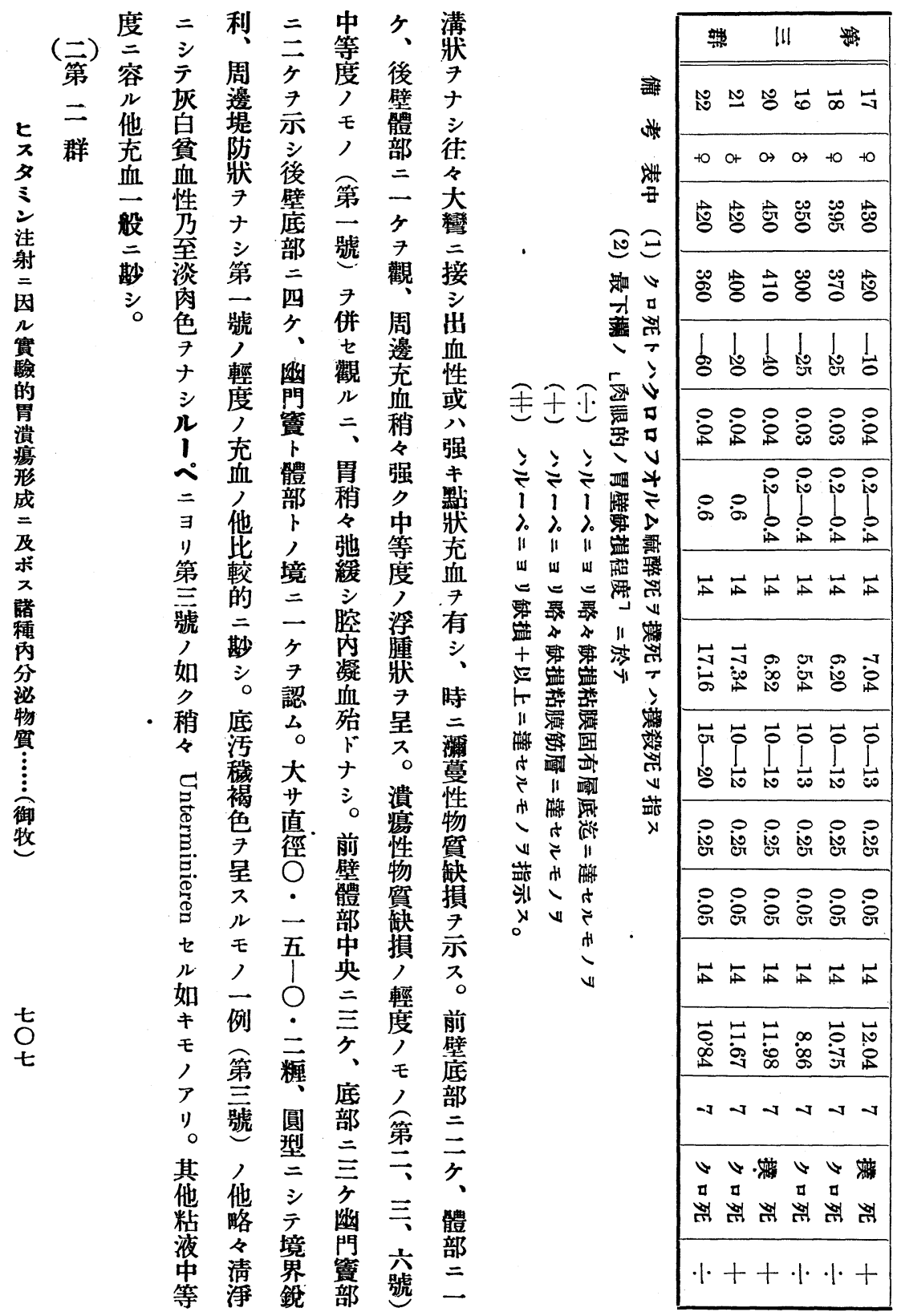


所 物

且 シ 膜周 $ᄌ$ テ圖乃 $\%$

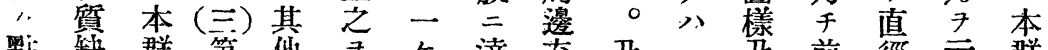

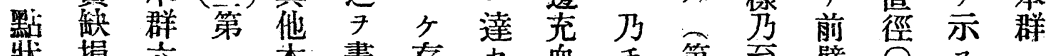

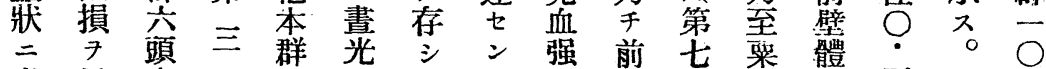

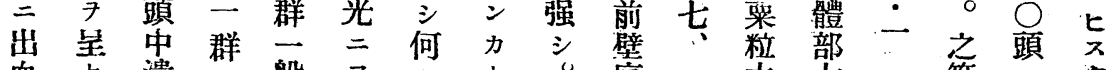

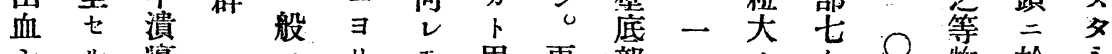

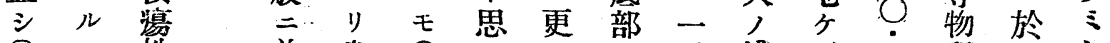

$\bigcirc$ 性 前生 $\bigcirc$ 八三 三 淺

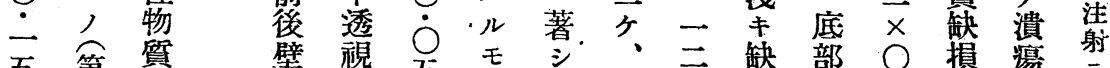

五第蒛 臂

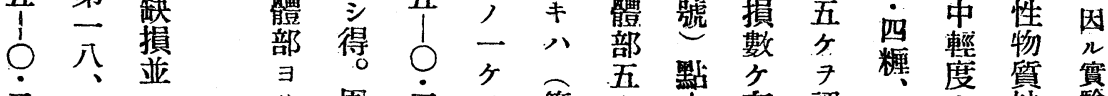

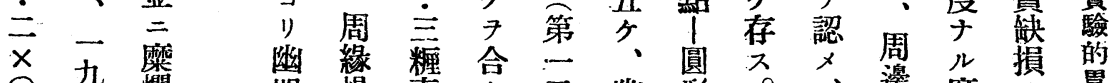

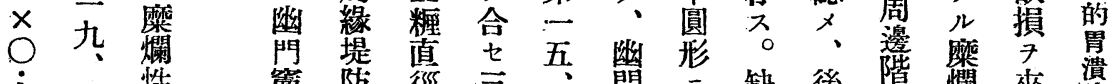

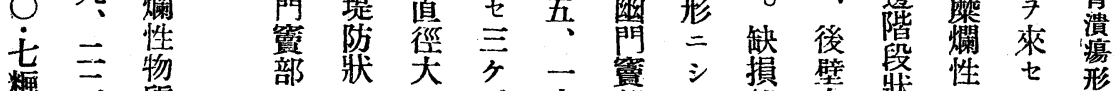

糎 三質

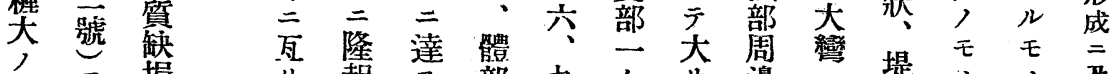

圆二損 リ起

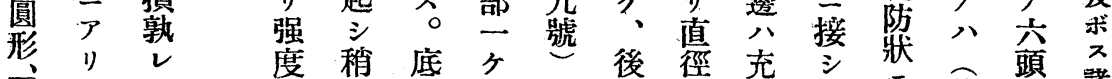

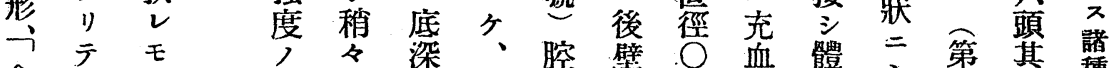

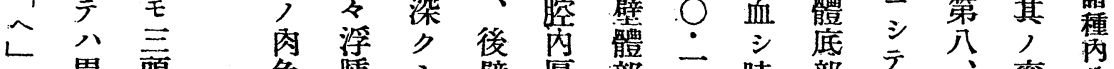

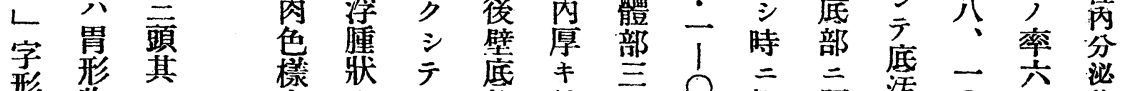

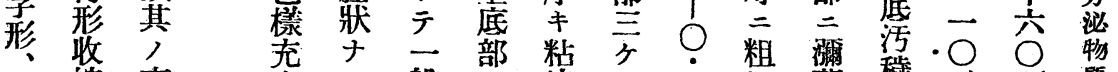

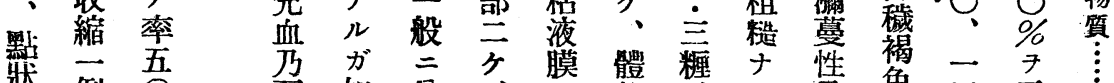

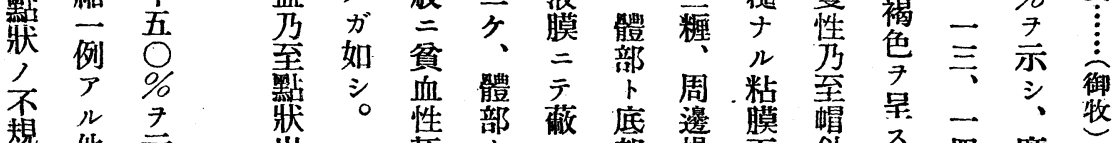

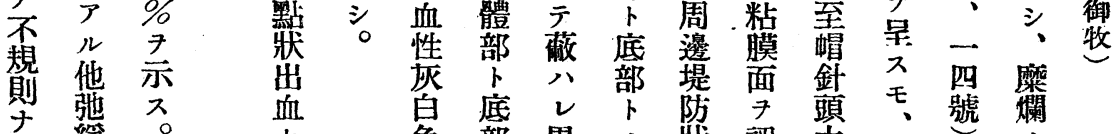

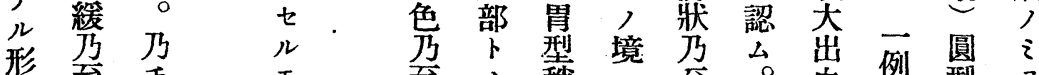

形至 $千$ 至, 䉘

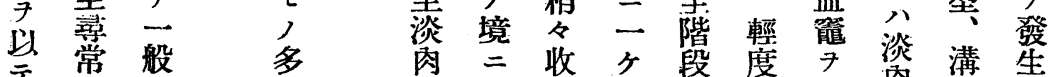

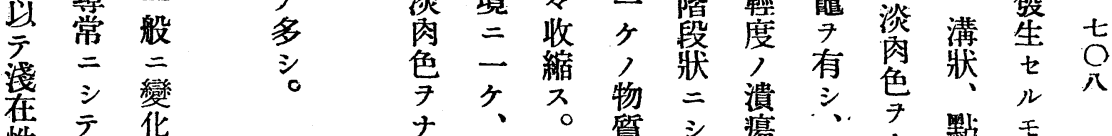

性㠜 輕

質 血 度

缺 少 二

䁚 量 シ

子 容 糜

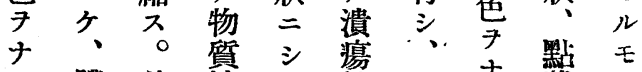

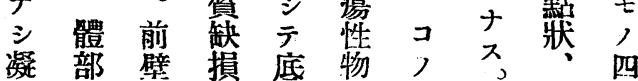

血中虚 7 活留内矩頭

7 央部有穢筷三第形其

附大 中 褐 損 不

七彎央、色三規 $\bigcirc$ シ 率

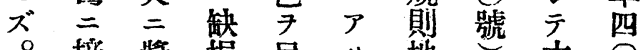




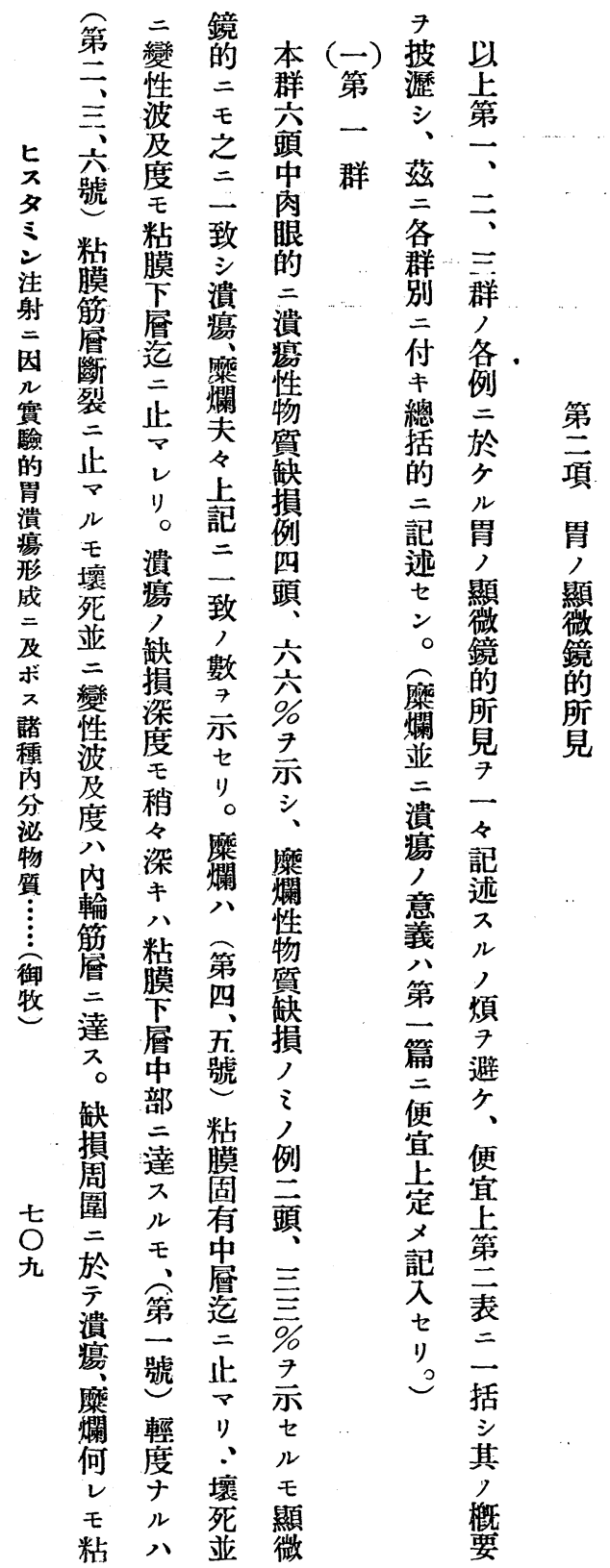

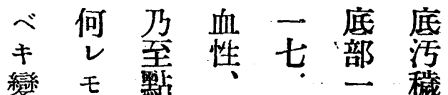
篟底牀 周三方裼

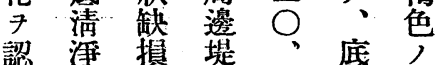
$x$ 灰 - 防二部他 元白少 牀

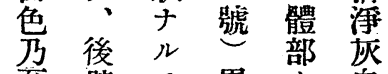
至 壁モ胃 卜 白 污幽㐬形簢急 褐簤輕緩二胬 色三度 三一色 于 接 三、ケ 旺 三 腔、是 ス 二示㐫幽 シ 他 $\dot{0}$ 缺筧管 触 性 $\times$ 少 部 損 牀？大 品周 前云彎。道啍

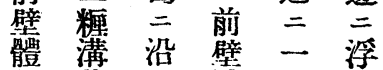

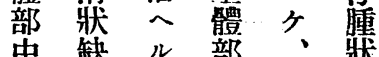
中筷 切部後獎 幽 斷 央 壁 少 門留、線幽體 部

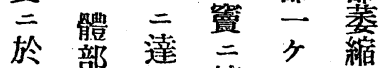
名袈接 7 紋 儿先。方生本 モ三冬紡 だ滑 二 三 體 綞り 略邊部形潰

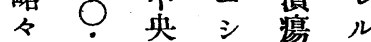
同 三 二 性 モ 涪榞 值 $\bigcirc$ 物, 其角豚方罍 ア 他形基 $\times$ 損。

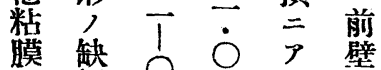
面損 ? 糎 y體

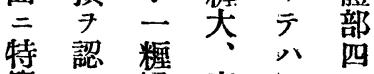

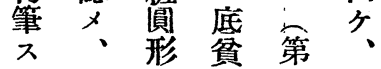


損 /肉眼的並二顯微鏡的所見)

\begin{tabular}{|c|c|c|c|c|c|c|c|c|c|c|c|c|c|c|c|c|}
\hline 亚 = & 其 & 图 专 & 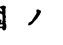 & 顯 & 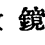 & & & & & & & & & & & \\
\hline 粘膜固 & 有層 & & $\begin{array}{l}\text { 粘膜管箭 } \\
\end{array}$ & & 粘 & 膜 & 下 & 層 & & 筋 & & 層 & & 膜 & & \\
\hline 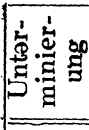 & 血 & $\begin{array}{l}\text { 出 } \\
\text { 血 }\end{array}$ & \begin{tabular}{|l} 
變 \\
\\
性
\end{tabular} & 血 & 血 & $\begin{array}{l}\text { 浮 } \\
\text { 腫 } \\
\end{array}$ & $\begin{array}{l}\text { 細 } \\
\text { 胞 } \\
\text { 浸 } \\
\text { 潤 } \\
\end{array}$ & \begin{tabular}{|l|} 
結增 \\
締 \\
蟣殖 \\
\end{tabular} & $\begin{array}{l}\text { 血 } \\
\text { 管 } \\
\text { 新 } \\
\text { 生 } \\
\end{array}$ & $\begin{array}{l}\text { 細 } \\
\text { 胞 } \\
\text { 浸 } \\
\text { 潤 } \\
\end{array}$ & $\begin{array}{l}\text { 肥 } \\
\text { 厚 } \\
\end{array}$ & $\mid \begin{array}{l}\mid \begin{array}{l}\text { 結增 } \\
\text { 締 } \\
\text { 織殖 }\end{array} \\
\end{array}$ & $\begin{array}{l}\text { 細 } \\
\text { 胞 } \\
\text { 浸 } \\
\text { 潤 } \\
\end{array}$ & 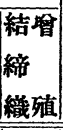 & $\begin{array}{l}\text { 潰 } \\
\text { 演 } \\
\end{array}$ & 闌 \\
\hline+ & + & + & - & - & + & - & H & \# & - & + & - & - & - & - & $H$ & \\
\hline+ & - & - & + & + & + & H & + & $H$ & - & - & - & - & - & - & + & \\
\hline+ & + & + & - & H & + & + & H & H & - & H & - & - & + & - & + & \\
\hline- & H & - & - & + & - & + & + & + & - & - & - & - & - & - & & H \\
\hline- & + & - & - & + & + & H & + & + & - & - & - & - & - & - & & + \\
\hline- & - & $H$ & - & + & + & + & $H$ & + & - & + & - & - & + & - & + & \\
\hline+ & 卅 & - & - & + & - & $H$ & $H$ & - & - & - & - & - & - & - & & \# \\
\hline+ & - & - & - & $H$ & - & - & - & - & - & - & - & - & - & - & & + \\
\hline H & $H$ & - & - & - & + & + & + & 卅 & - & $H$ & - & - & - & - & 卅 & \\
\hline- & + & - & - & $H$ & H & - & - & - & - & - & - & - & - & - & & + \\
\hline+ & - & - & - & - & + & - & + & + & - & - & - & - & - & - & + & \\
\hline- & - & - & - & H & - & H & + & - & - & - & - & - & - & - & + & \\
\hline- & + & - & - & + & - & - & - & - & - & - & - & - & - & - & & + \\
\hline- & + & - & - & - & - & - & + & + & - & - & - & - & - & - & & $H$ \\
\hline- & $H$ & - & - & + & + & + & + & $H$ & - & - & - & - & - & - & H & \\
\hline+ & H & - & - & + & + & - & + & H & - & - & - & - & - & - & $H$ & \\
\hline+ & + & - & - & H & Ht & + & H & \# & $H^{\mathrm{e}}$ & - & - & - & - & - & + & \\
\hline- & + & - & - & - & - & - & - & - & - & - & - & - & - & - & & + \\
\hline
\end{tabular}


第二表（物 質 缺

\begin{tabular}{|c|c|c|c|c|c|c|c|c|c|}
\hline \multirow[b]{2}{*}{ 別 } & \multirow{2}{*}{$\begin{array}{l}\text { 海 } \\
\text { 獏 } \\
\text { 番 } \\
\text { 號 }\end{array}$} & \multirow{2}{*}{$\begin{array}{l}\text { 性 } \\
\text { 別 }\end{array}$} & \multicolumn{4}{|c|}{ 肉 眼 的 所 見 } & \multicolumn{3}{|c|}{ 缺 描 } \\
\hline & & & 形 & $\begin{array}{c}\text { 大 直 } \\
\text { サ 徑 } \\
\text { (糎) } \\
\end{array}$ & 淺 & 底 & $\begin{array}{c}\text { 缺 樑 } \\
\text { 損 度 }\end{array}$ & $\begin{array}{l}\text { 壤 變 波 } \\
\text { 烈性及 } \\
\text { 亚 波度 }\end{array}$ & 增 \\
\hline 第 & 1 & $\delta$ & 圓 & 0.15 & 堤防狀 & $\begin{array}{l}\text { 晴淨 } \\
\text { 淡肉色 }\end{array}$ & $\begin{array}{l}\text { 粘膜下層 } \\
\text { 中 部 迄 }\end{array}$ & $\begin{array}{l}\text { 內輪能層 } \\
\text { 汽 }\end{array}$ & + \\
\hline & 2 & 우 & 圓 & 0.2 & 堤防狀 & $\begin{array}{l}\text { 清淨 } \\
\text { 淡肉色 }\end{array}$ & 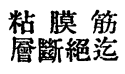 & $\begin{array}{l}\text { 粘膜筋䚄 } \\
\text { 迄 }\end{array}$ & + \\
\hline 一 & 3 & 우 & 圓 & 0.15 & 堤防狀 & $\begin{array}{ll}\text { 污 械 } \\
\text { 褐 色 }\end{array}$ & 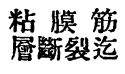 & $\begin{array}{l}\text { 粘膜下層 } \\
\text { 汔 }\end{array}$ & H \\
\hline & 4 & 우 & 矩形 & $0.1 \times 0.2$ & 堤防狀 & $\begin{array}{ll}\text { 污 稢 } \\
\text { 褐 色 }\end{array}$ & $\begin{array}{l}\text { 粘膜固有 } \\
\text { 皤中部迄 }\end{array}$ & $\begin{array}{l}\text { 粘膜下層 } \\
\text { 染 }\end{array}$ & - \\
\hline 群 & 5 & $\hat{o}$ & 圓 & 0.2 & 堤防狀 & $\begin{array}{ll}\text { 污 穖 } \\
\text { 褐 色 }\end{array}$ & $\begin{array}{l}\text { 粘膜固有 } \\
\text { 皤上部艺 }\end{array}$ & $\begin{array}{l}\text { 粘膜下㾘 } \\
\text { 上部 }\end{array}$ & - \\
\hline & 6 & 우 & 圓 & 0.2 & 噴火口狀 & $\begin{array}{l}\text { 清 淨 } \\
\text { 賽血性 }\end{array}$ & 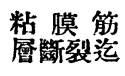 & $\begin{array}{l}\text { 粘膜下佮 } \\
\text { 底 部迄 }\end{array}$ & 十 \\
\hline & 7 & ㅇ & 點 & 0.1 & 堤防狀 & $\begin{array}{l}\text { 污 穖 } \\
\text { 黃 色 }\end{array}$ & $\begin{array}{l}\text { 粘膜固有 } \\
\text { 㞒 㭽 }\end{array}$ & $\begin{array}{l}\text { 粘膜固有 } \\
\text { 層底汔粘 }\end{array}$ & - \\
\hline & 8 & $\hat{o}$ & 圓 & 0.2 & 階段狀 & $\begin{array}{l}\text { 活 穖 } \\
\text { 褐 色 }\end{array}$ & $\begin{array}{l}\text { 粘膜固有 } \\
\text { 畨上部汽 }\end{array}$ & $\begin{array}{l}\text { 膜層上部 } \\
\text { 迄 }\end{array}$ & - \\
\hline 第 & 9 & $\delta$ & 點 & 0.05 & 堤防狀 & $\begin{array}{l}\text { 清 淨 } \\
\text { 覓血性: }\end{array}$ & $\begin{array}{l}\text { 外縱筋層 } \\
\text { 迄 }\end{array}$ & $\begin{array}{l}\text { 外縱筋膡 } \\
\text { 迄 }\end{array}$ & Ht \\
\hline & 10 & $\hat{\delta}$ & 满 & $0.1 \times 0.7$ & 堤防狀 & $\begin{array}{l}\text { 淡肉色 } \\
\text { 清 淨 }\end{array}$ & $\begin{array}{l}\text { 粘膜固有 } \\
\text { 愿上部汽 }\end{array}$ & $\begin{array}{l}\text { 粘膜固有 } \\
\text { 層上部迄 }\end{array}$ & + \\
\hline 二 & 11 & $\hat{o}$ & 圓 & 0.3 & 階段狀 & $\begin{array}{ll}\text { 活 峨 } \\
\text { 褐 色 }\end{array}$ & $\begin{array}{l}\text { 粘膜筋 } \\
\text { 斷㲊裂迄 }\end{array}$ & $\begin{array}{l}\text { 外縱筋䚄 } \\
\text { 汽 }\end{array}$ & + \\
\hline & 12 & 우 & 圓 & 0.2 & 堤防狀 & 褐色々污稚 & $\begin{array}{l}\text { 粘膜筋 } \\
\text { 厤断裂迄 }\end{array}$ & $\begin{array}{l}\text { 粘膜筋層 } \\
\text { 汽 }\end{array}$ & + \\
\hline & 13 & 우 & 點 & 0.1 & 階段狀 & $\begin{array}{l}\text { 污 穖 } \\
\text { 褐 色 }\end{array}$ & $\begin{array}{l}\text { 粘膜固有 } \\
\text { 㞒上部迄 }\end{array}$ & $\begin{array}{l}\text { 粘膜固有 } \\
\text { 㲊中部迄 }\end{array}$ & - \\
\hline 群 & 14 & 우 & 矩形 & $0.2 \times 0.4$ & 階段狀 & $\begin{array}{ll}\text { 污 欈 } \\
\text { 褐 色 }\end{array}$ & $\begin{array}{l}\text { 粘膜固有 } \\
\text { 曆中部迄 }\end{array}$ & $\begin{array}{l}\text { 粘膜固有 } \\
\text { 漛中部汽 }\end{array}$ & - \\
\hline & 15 & $\delta$ & 圓 & 0.3 & 堤防狀 & $\begin{array}{l}\text { 淡肉色 } \\
\text { 充 血 }\end{array}$ & $\begin{array}{l}\text { 粘膜下㞗 } \\
\text { 中 部 }\end{array}$ & $\begin{array}{l}\text { 粘膜下観 } \\
\text { 底 }\end{array}$ & + \\
\hline & 16 & 우 & 圓 & 0.2 & 堤防狀 & $\begin{array}{l}\text { 清 淨 } \\
\text { 䀜血性 }\end{array}$ & $\begin{array}{l}\text { 粘膜下䚄 } \\
\text { 底 部 }\end{array}$ & $\begin{array}{l}\text { 内輪筋層 } \\
\text { 汽 }\end{array}$ & - \\
\hline 第 & 17 & 우 & 三角 & 0.2 & 階段狀 & $\begin{array}{l}\text { 清 淨 } \\
\text { 在白色 }\end{array}$ & $\begin{array}{l}\text { 粘膜筋䚄 } \\
\text { 斷絕 迄 }\end{array}$ & $\begin{array}{l}\text { 粘膜筋層 } \\
\text { 艺 }\end{array}$ & + \\
\hline & 18 & 우 & へ字 & $0.2 \times 0.7$ & $\begin{array}{l}\text { 階段狀 } \\
\text { 堤防狀 }\end{array}$ & $\begin{array}{l}\text { 清 淨 } \\
\text { 灰白色 }\end{array}$ & $\begin{array}{l}\text { 粘膜固有 } \\
\text { 啳上部迄 }\end{array}$ & $\begin{array}{l}\text { 粘膜固有 } \\
\text { 㲊中部迄 }\end{array}$ & - \\
\hline
\end{tabular}




\begin{tabular}{|c|c|c|c|c|c|c|c|c|c|c|c|c|c|c|c|c|}
\hline \multicolumn{15}{|c|}{ 並 = 其周圍, 顯 微鏡的所見 } & \multirow{2}{*}{\multicolumn{2}{|c|}{$\begin{array}{l}\text { 顯微鏡 } \\
\text { 的缺損 } \\
\text { 程变 }\end{array}$}} \\
\hline \multicolumn{3}{|c|}{ 貼膜固有層 } & \multirow{2}{*}{$\begin{array}{l}\text { 粘膜 } \\
\text { 筋櫫 } \\
\text { 變 } \\
\end{array}$} & \multicolumn{2}{|r|}{ 粘 } & 膜 & \multicolumn{3}{|c|}{ 下 霄 } & \multicolumn{2}{|c|}{ 筋 } & & & & \\
\hline م. & 充 & 血 & & 充 & 血 & 浮 & $\begin{array}{l}\text { 細 } \\
\text { 胞 } \\
\text { 浸 } \\
\text { 潤 } \\
\end{array}$ & $\mid \begin{array}{l}\text { 結䝬 } \\
\text { 締 } \\
\text { 織殖 } \\
\end{array}$ & $\begin{array}{l}\text { 血 } \\
\text { 管 } \\
\text { 亲 } \\
\text { 正 }\end{array}$ & $\begin{array}{l}\text { 綀 } \\
\text { 胞 } \\
\text { 浸 } \\
\text { 潤 } \\
\end{array}$ & $\begin{array}{l}\text { 肥 } \\
\text { 厚 }\end{array}$ & $\mid \begin{array}{l}\left|\begin{array}{l}\text { 結增 } \\
\text { 締 } \\
\text { 織殖 }\end{array}\right| \\
\end{array}$ & $\begin{array}{l}\text { 細 } \\
\text { 胞 } \\
\text { 浸 } \\
\text { 潤 } \\
\end{array}$ & 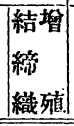 & $\begin{array}{l}\text { 溳 } \\
\text { 演 } \\
\end{array}$ & 碳 \\
\hline- & + & - & - & - & - & - & - & - & - & - & - & - & - & - & & + \\
\hline- & - & - & - & - & + & + & + & H & - & - & - & - & - & - & + & \\
\hline - & - & - & $H$ & $\#$ & H & - & - & H & - & - & - & - & - & - & + & \\
\hline+ & H & HI & $H$ & $H$ & H & $t$ & HI & H & - & - & - & - & - & - & & H \\
\hline
\end{tabular}

ス。

ヨ示シーハ全ク所見ナキヨ指示ス。

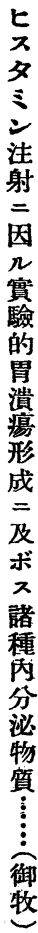

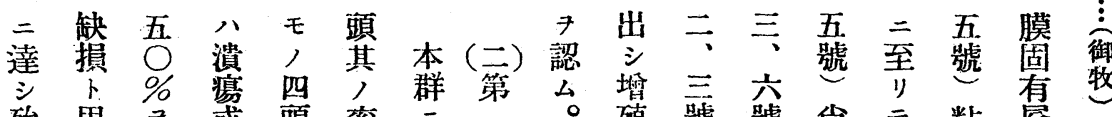
殆 思 7 或 頭 率 三 三 粘

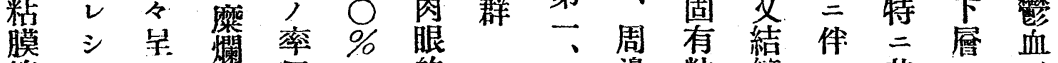

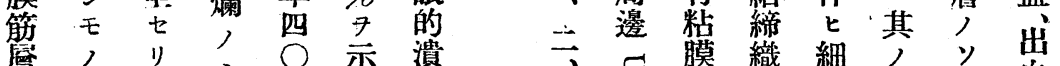
曆

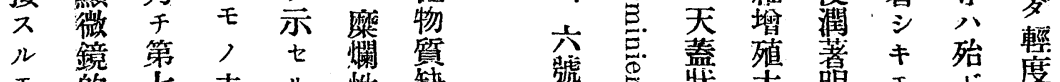

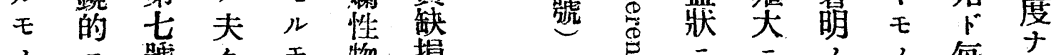

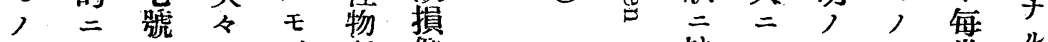
二粘ノ五、賢例 七缺 シ モ ア 常王

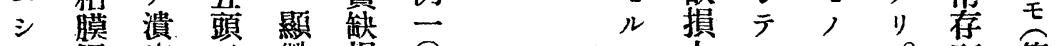
テ固 瘍 微 損 $\bigcirc$ 上 $\frown \frown 乞$ 在第 二㤫性其 镜 $ノ$ 頭部第第第

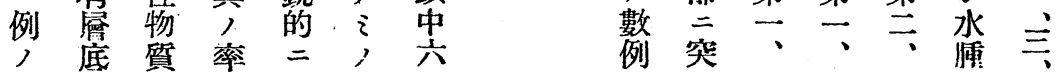




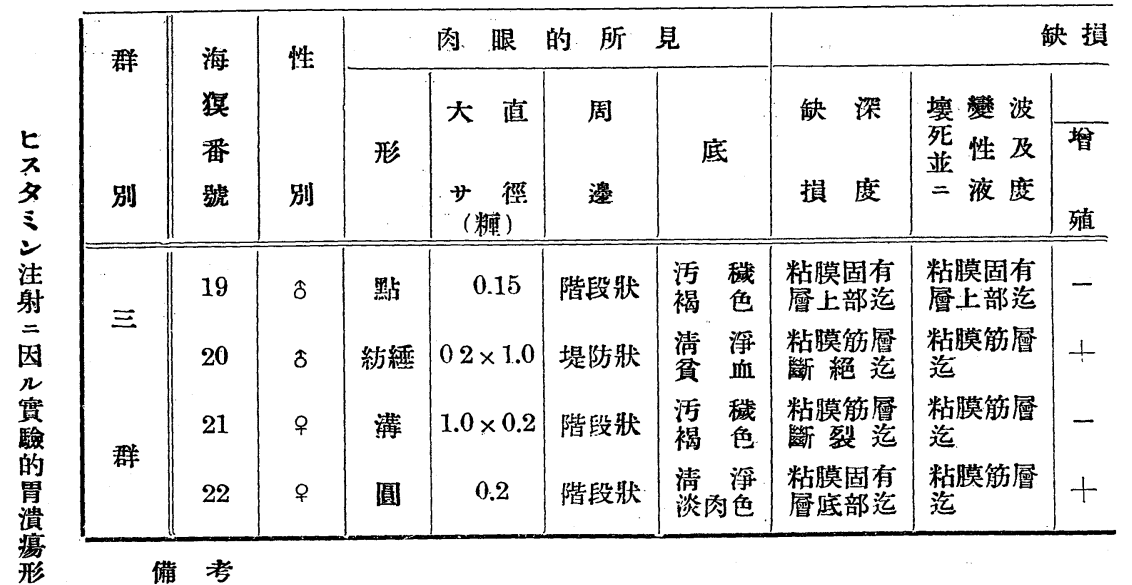

（1）各例中／所見八其/例二於テ發生七几物質缺撌/中代表的ノモノ

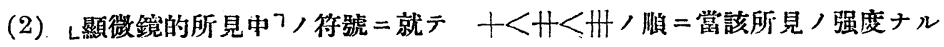

（3） L顯微鏡的缺損程度 7 中/符號二就テ

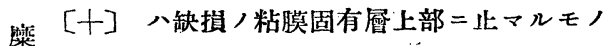

[H] 八缺摃/粘膜固有㬐中部二止マルモ,

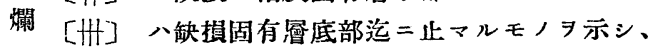

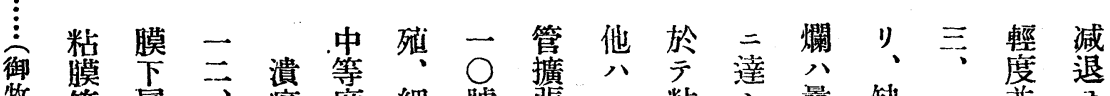

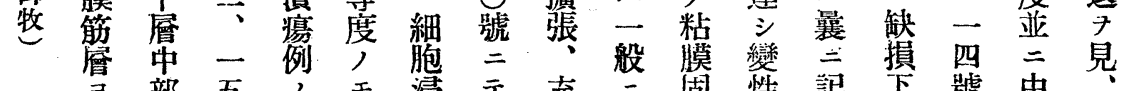

$\exists$ 部五, 壬浸テ充二固性記算號中学

リ”之輕, 潤八盈輕有攴七, 等之

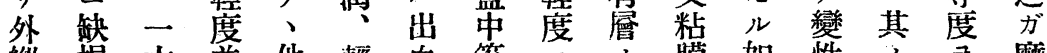

縱 損 宍並 他輕 血等 二, 膜 如性, 7 様

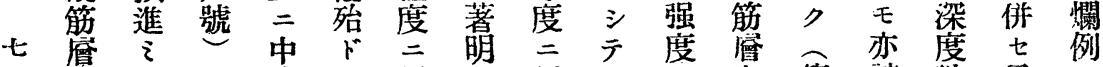

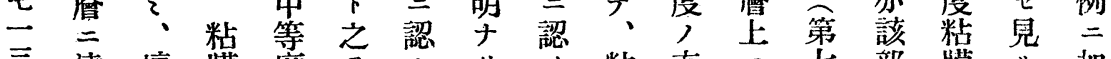

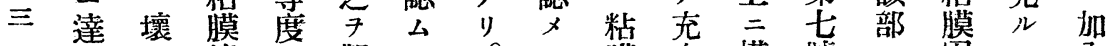

ス 死筋二觀 ル

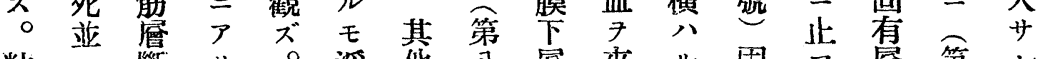

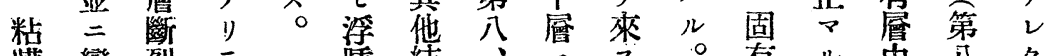

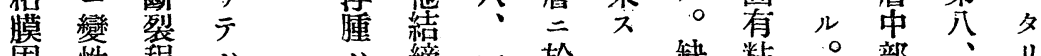

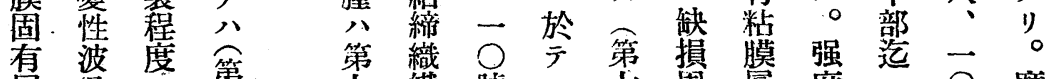

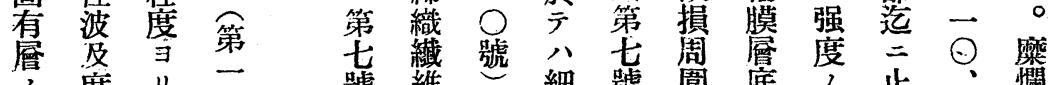

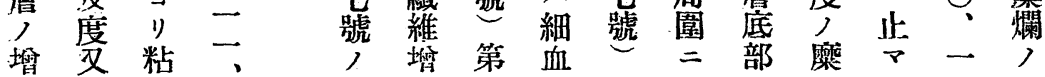




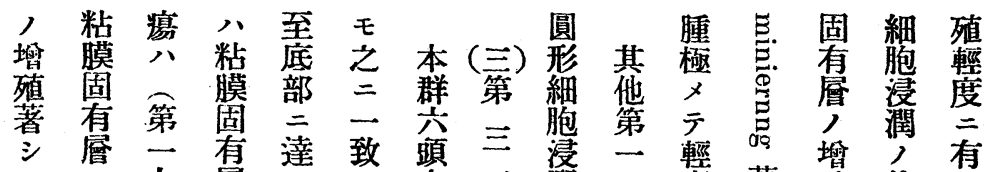

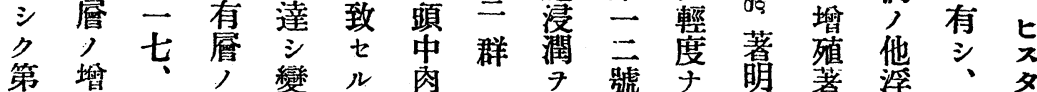

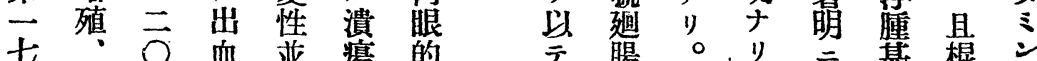

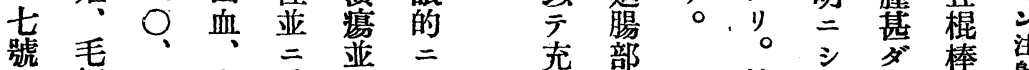

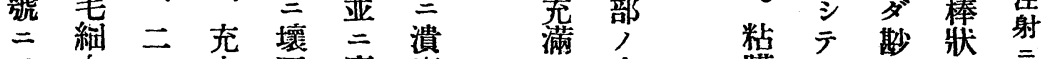

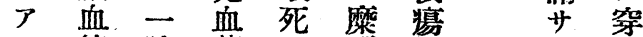

リ管 號 著 数 爛 性我 テ擴 明膜 7 物腸部

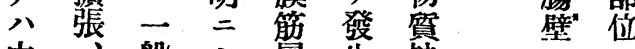

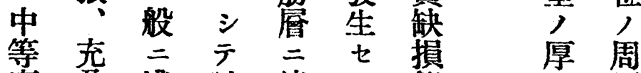

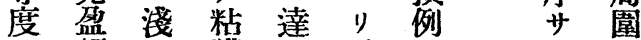

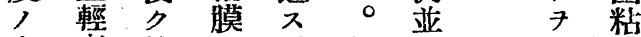

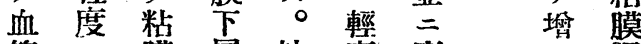

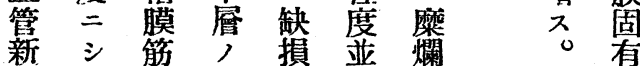
生示层細周三性而詹

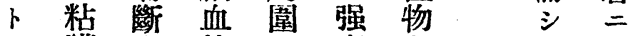
共膜裂管, 度留产强

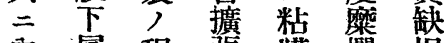

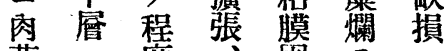

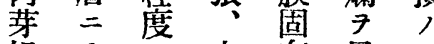
組玄三充有見i 樴公言盛潅光, 7 充示具, = 作血壤出整签， 流死葷第夫 了出篮細充分名 。變脃血、頍 浮細性漫幕一其 崕胞玉满入九， 八浸赤著几率

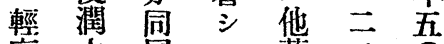

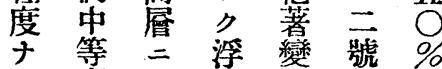

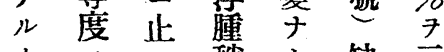

力文稍 $¥$ 缺示

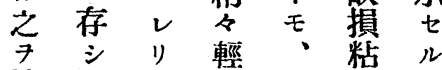
缺。。度第視毛

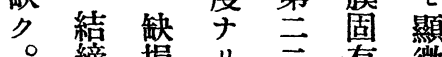

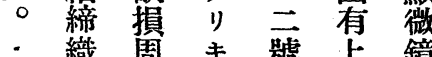

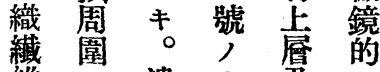

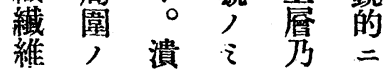

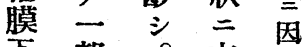

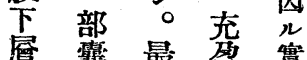

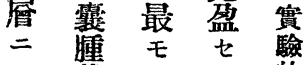
厂獎强儿的 八度 $モ$ 睍 签呈子, 輜 度七儿了笄 儿潰”成 出腺㾤 血 組 分及 他織第第委

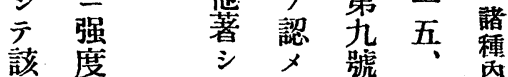

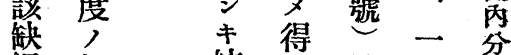
損 細 部胞

溷

㜠 7

來

從

七 粘

腸 膜

粘 下

膜 㫤

固

有 赤

詹 血

八球

般 恶

莣涺

菱走

箱学

”。

夥
結 蒛六永

楴 ク損 號 物

織、亚 犋

䋺毛些粘

維 紲變 笶

增管学 層 製

殖, 至,

棍壞輕

共棒死 “度

二狀外,

輕 擴 縱 充

了亚㡺 出

出竞澾出西

血斋達

細学、結

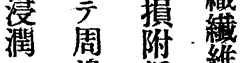

7 邉近維

認导粘霣
度張筋 血

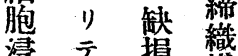




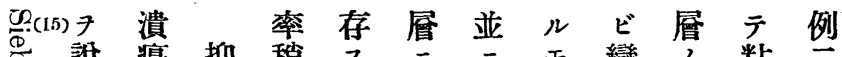

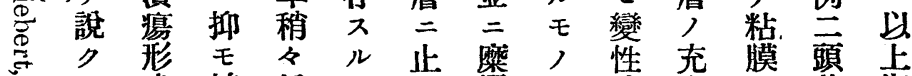

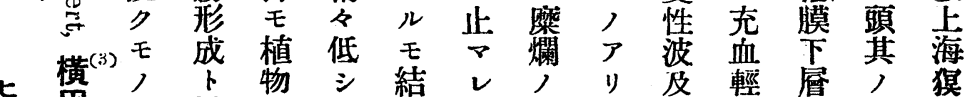

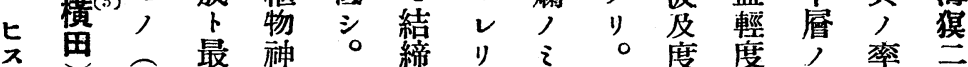

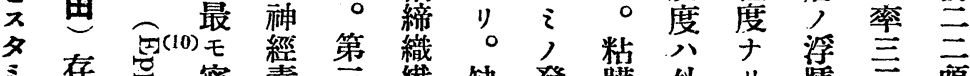

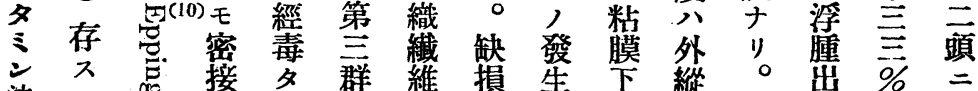

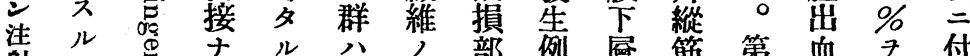
$=、 \approx$ ピ第增周 何二詹三、示 因 横 ${ }^{(3)}$ 關 只殖邊 出 几思係カ群著三モ血達、血、驗

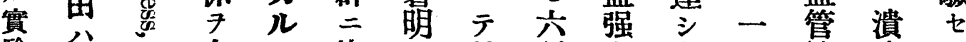

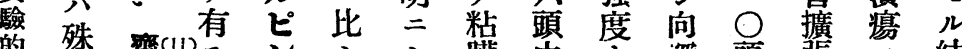
的殊

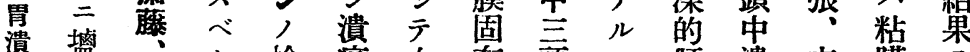

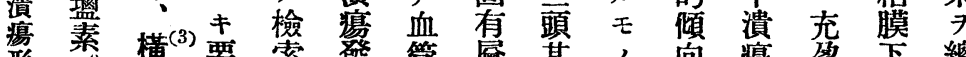

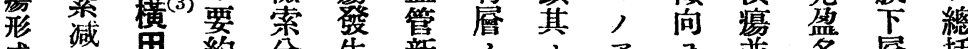

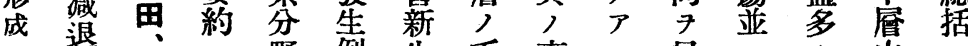
及時山(12) 就野荎生毛率儿見二ク中ス

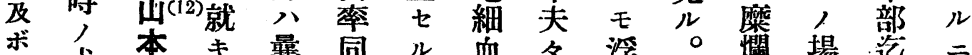

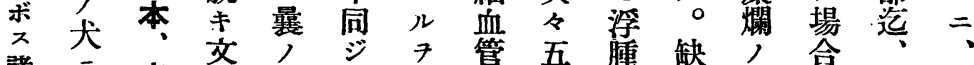

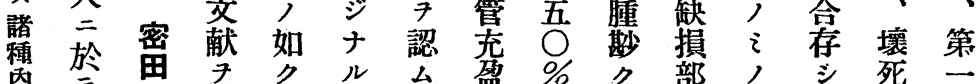

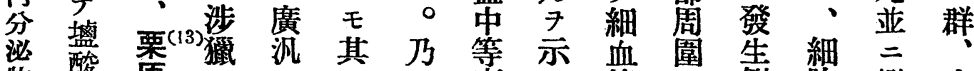

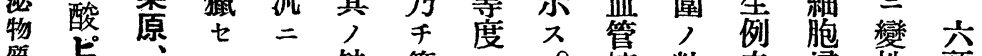
啠

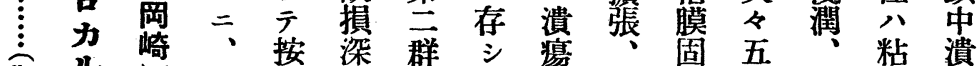

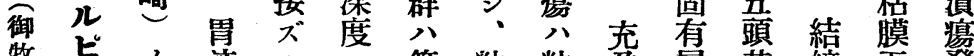

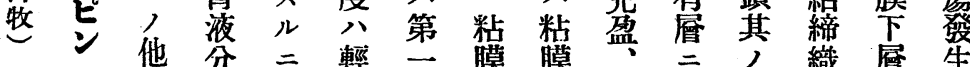

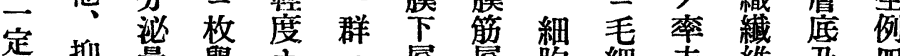
量㫼量舉子層詹胞細夫維乃四 適子制三り比, 斷浸血々) 至頭

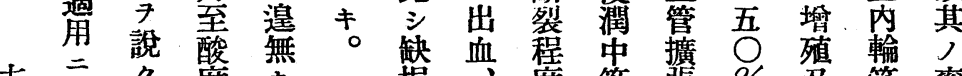
七

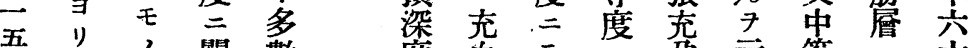

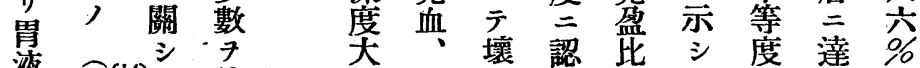

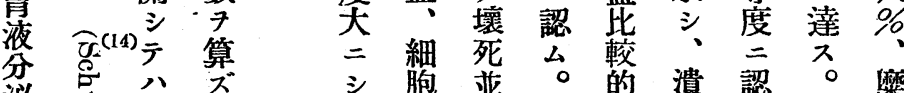
汼高其

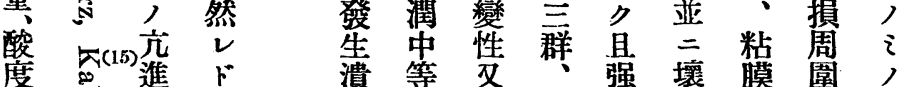
度恕隻 他气用胃例三筋潰度死固云登 
ンタ血器管大二同度ルナ蛋

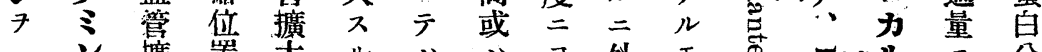

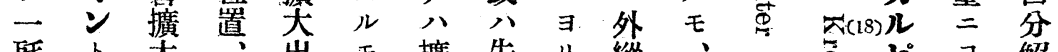

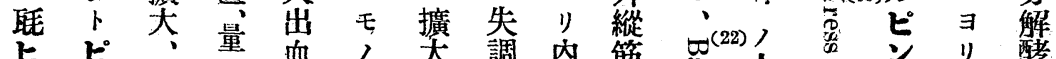

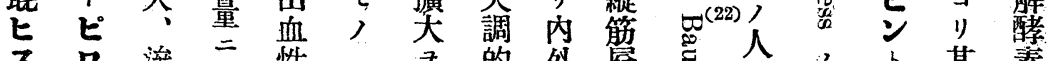
万品

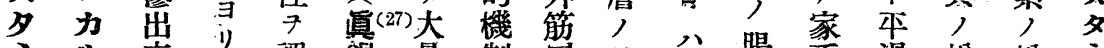

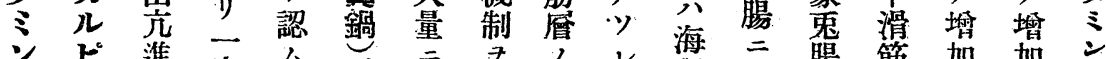

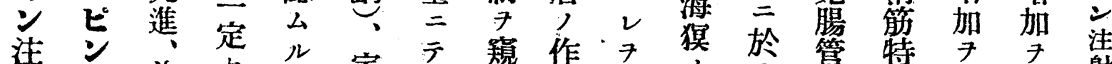

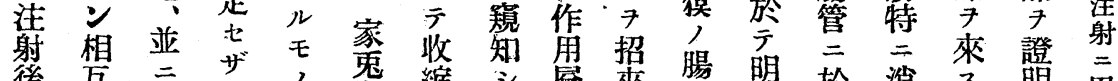

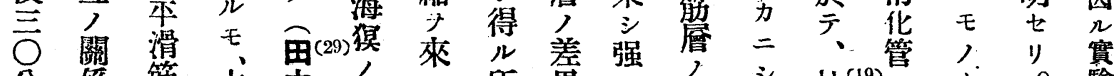
分係䇫大虫肺

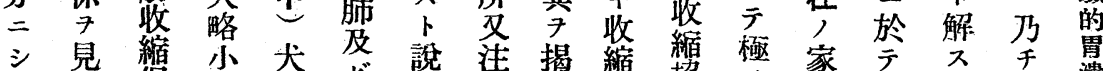

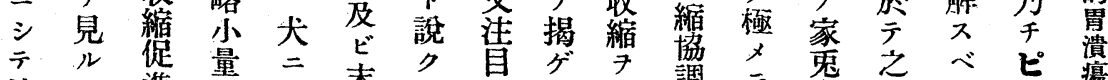

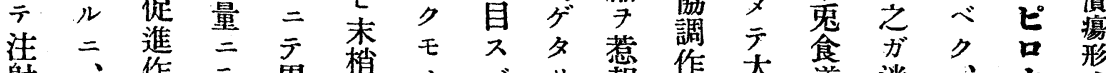

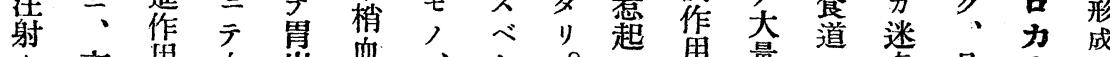

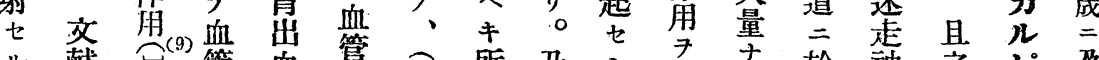

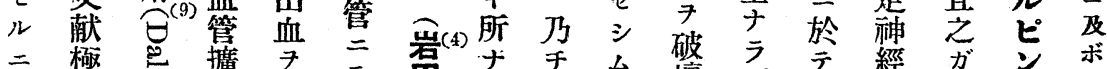

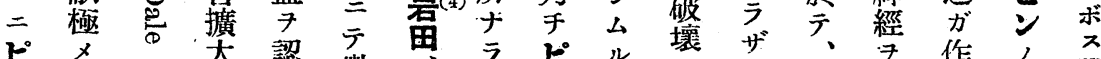

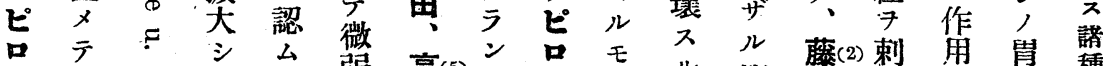

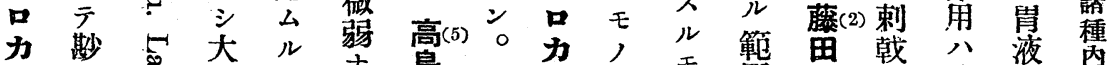

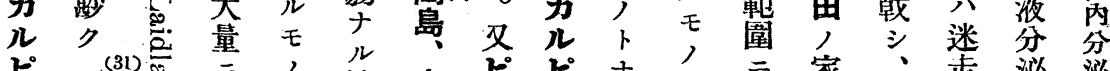

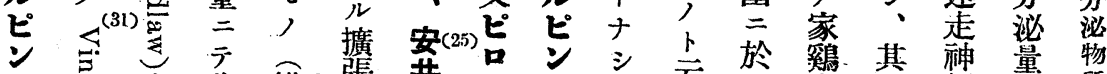

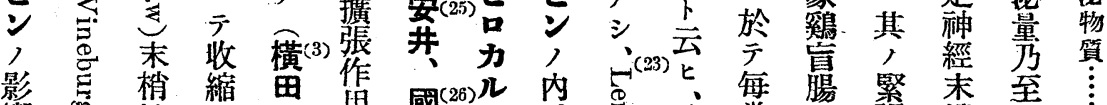

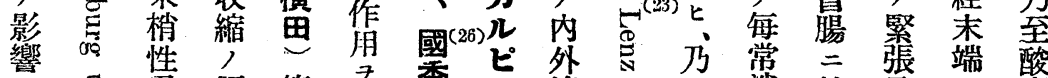

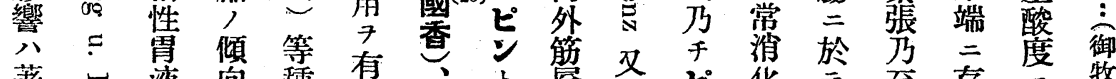

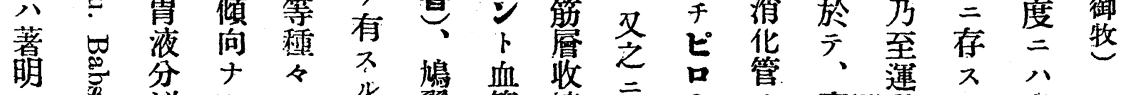

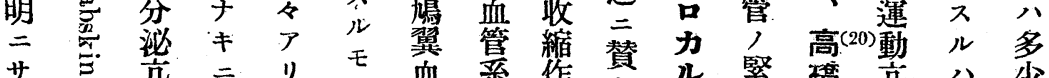

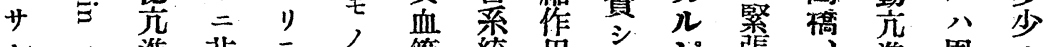
レ八進非 $テ$ 管統用、ピ張、進周、 或 莋

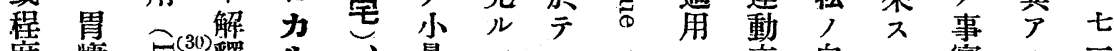
度 褛 分 作 鸪

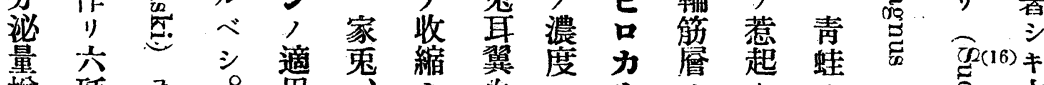

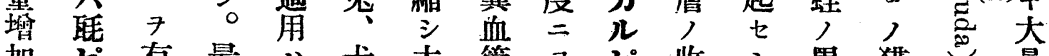
贺 占 有 最公犬 太量管 ビカル 物毛云其溶終 ル於管次

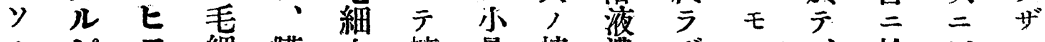

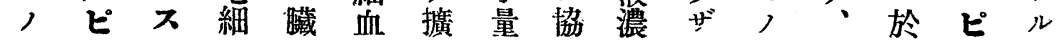


ン粘合ナ屋人カシ シ 暴如增其口的時

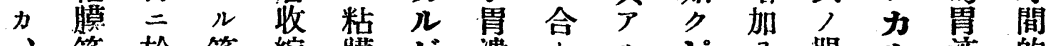

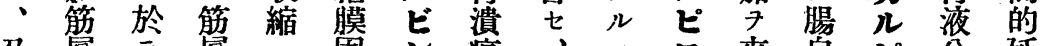

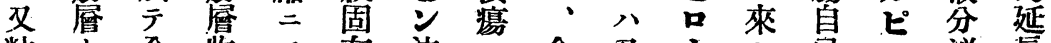

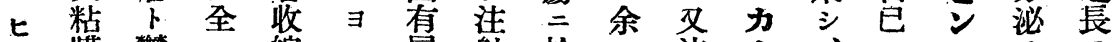

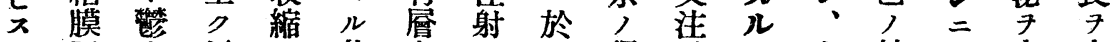
夕下血 反三其充 $三$ 得自 ピ生敏 $コ$ 來. 來

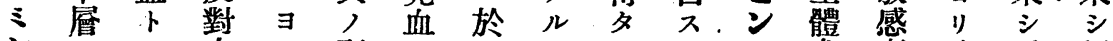

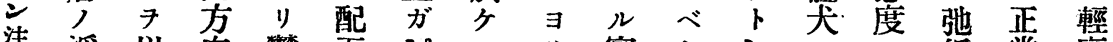

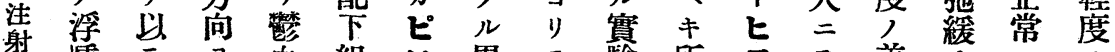

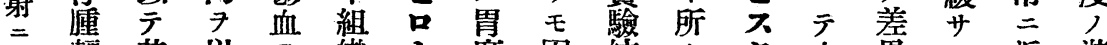

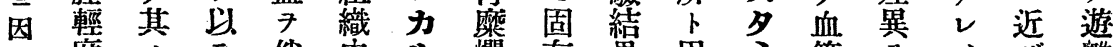
$几$ 度

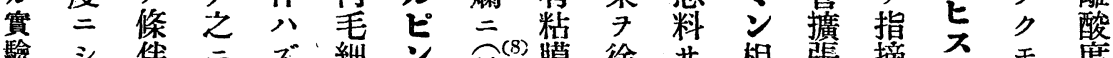

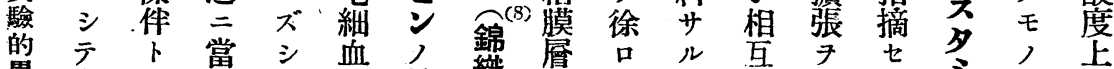

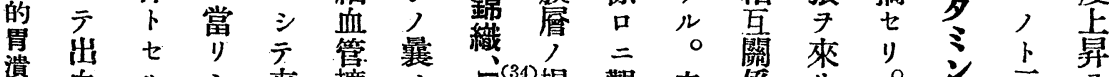

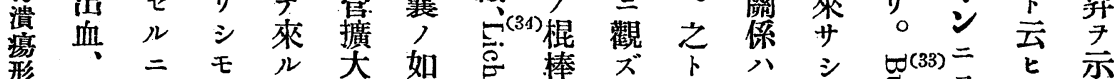

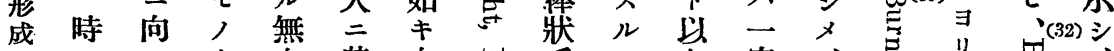

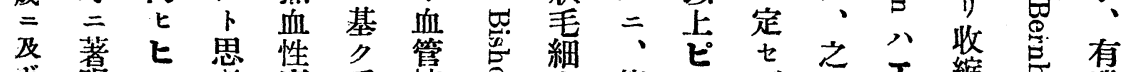

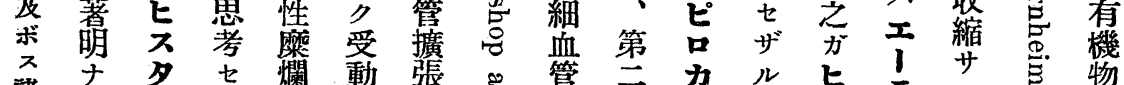
諸ナタセ爛 動 張 管 種儿隹 永ピ等

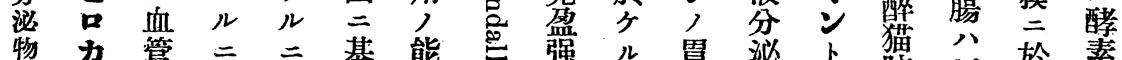

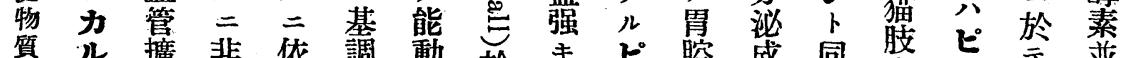

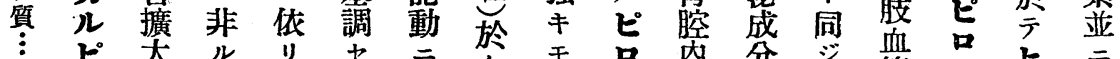
Łピルリ七 御性ガテル依ル, カ酸, 作官西不酸

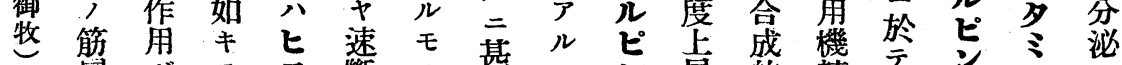
詹方モ

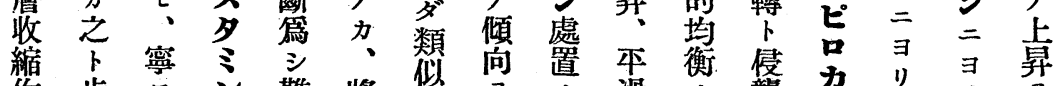

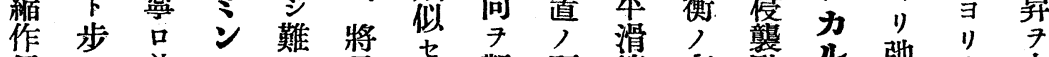

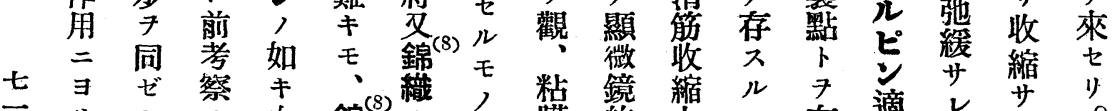

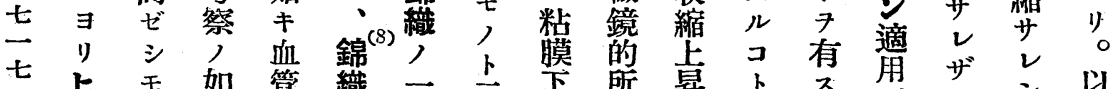

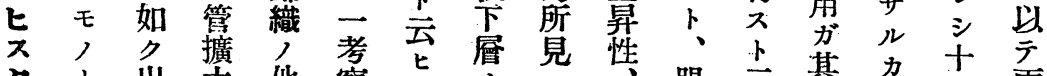
夕卜出犬他察得了二腸云其吕士雨

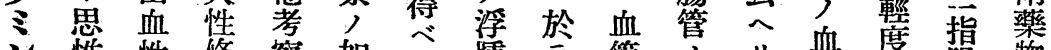

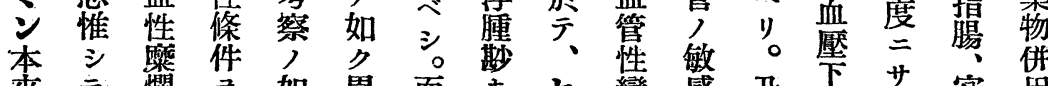

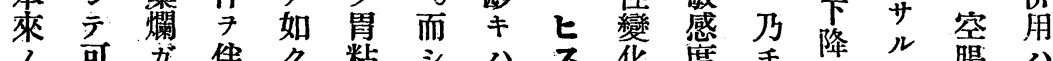
可吕件名粘シ心花度手降心゙腸八

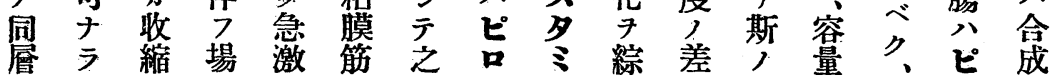




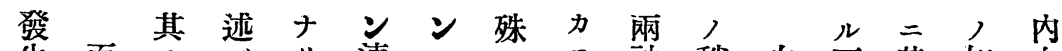
生而了心芯連 $三$ 二栭稍次要基如血

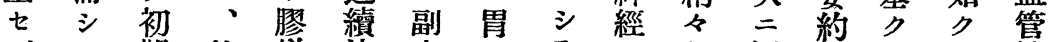

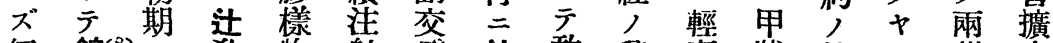

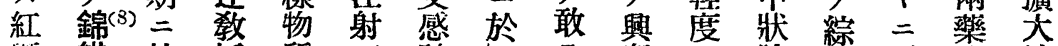

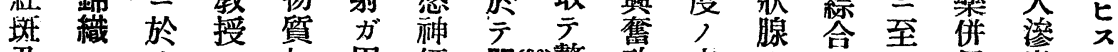

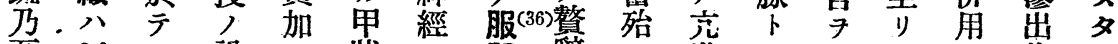

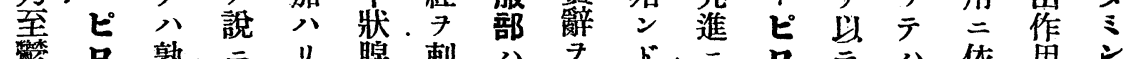

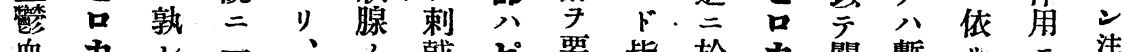

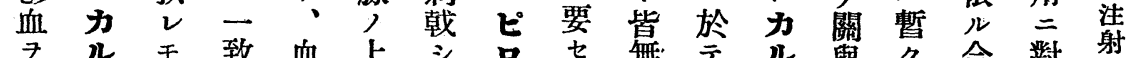

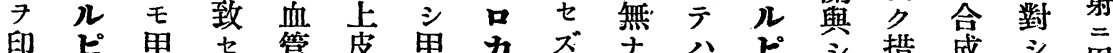

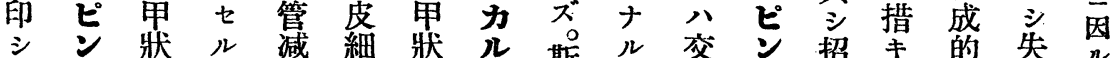

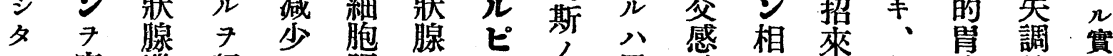

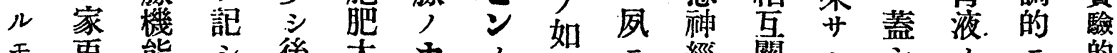

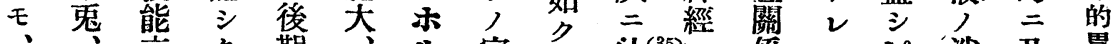

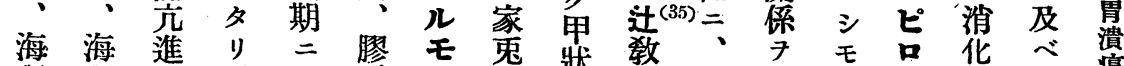

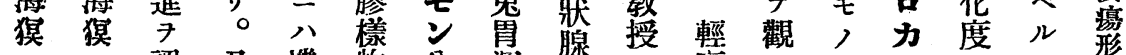

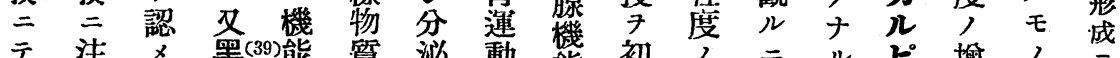

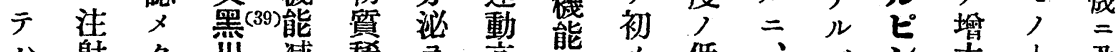

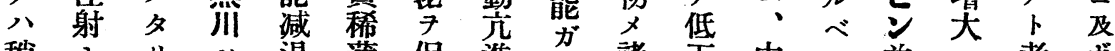

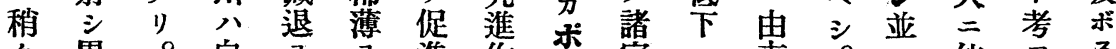

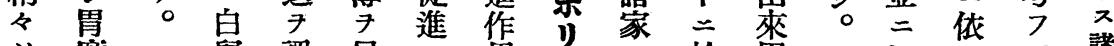

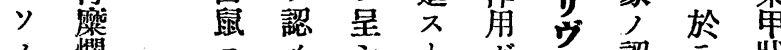
爛 二 敏 ヨ ピ:・云甲 感形吕之甲へ牀ンラ荠機 度成カガ狀ル腺トル感能

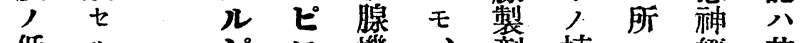

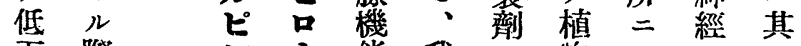

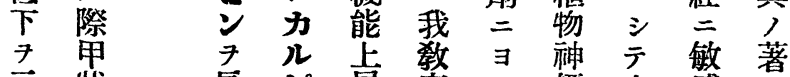
示牀 長 ピ泉等当經之感音

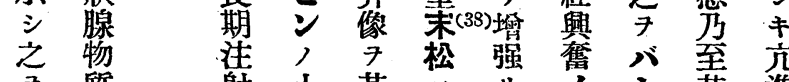

質 射小其分严

動 7 量了白ルカだ

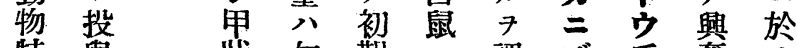

特興牀勿期三認 ズ 氏 奮 テ

暴 $t$ 腺 論二於 $x$ 么 病性 八

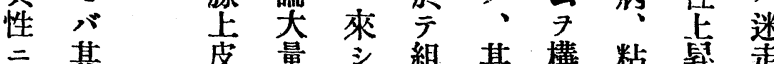

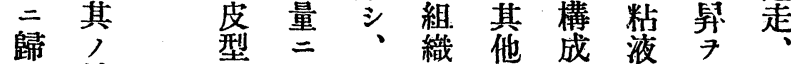

七適 7 於漸學 笑 ${ }^{(37)}$ 水來

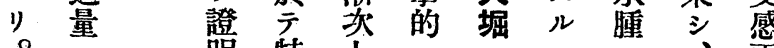

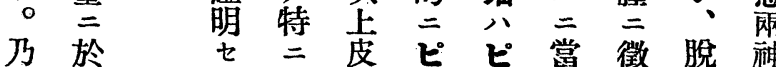

手方 於著皮 ピ ピ

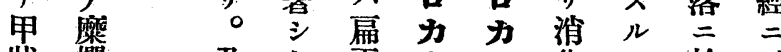

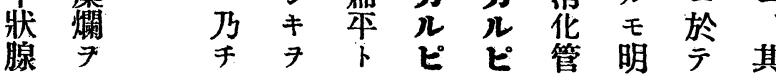

腺 $尹$

ピ ピ 管 明 テ 其

七ル 譇

スモク楀

夕, 甫分

思思㘥物 各思推 梁 各节梁 特毛嘴御

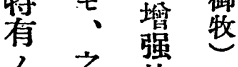
血㤎的 管 第 向 俑次勇 的

胃ナ壁り量 筋 $\rightarrow>$

㤦 血

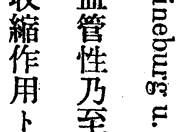

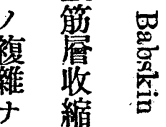




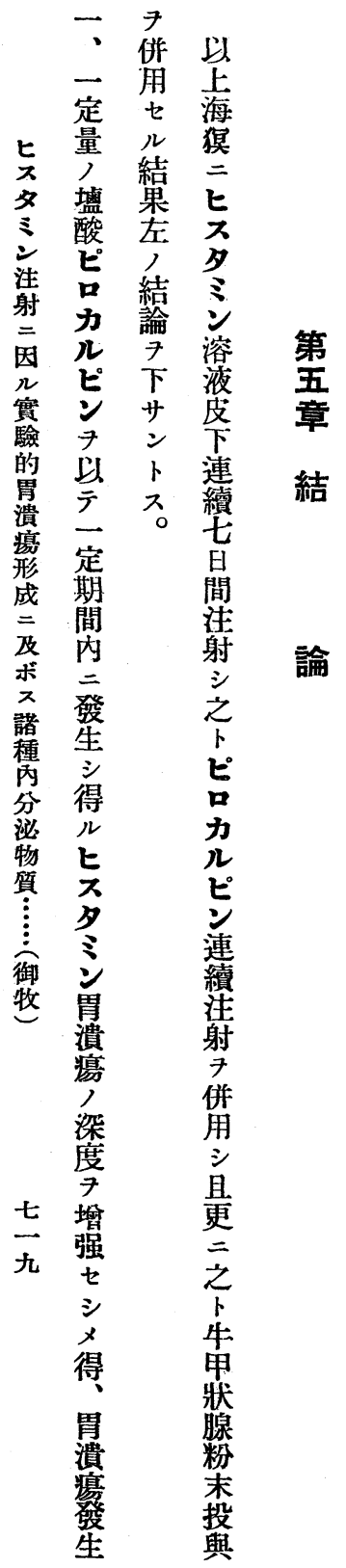

投膜

興下ルョ機進只法攴喘犋 公漛所示能像甸息投 ピ血ナスノ方狀適子興 口管 公行見腺角以伴三 力性モ及公樣主厅人日 ル失: 偶ルカ能體迷迷ル ピ 調 蓋然八之㐬二走走 荾 斗 $三$ 自卜進 $\exists$ 神神感 人輕甲非亏甲 迷减狀 天゙推狀 於兩, 䕟 經 走湶卜知腺亏神緊奮䇣

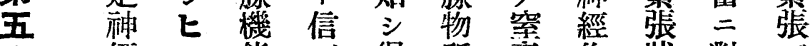
章經 ス能ズ得質素作牀對分

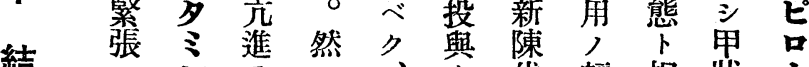
$=\geqslant \ni v 、$ 代輕相狀力 拮本以

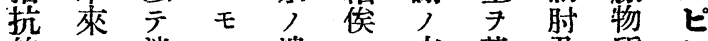

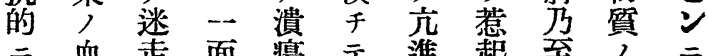

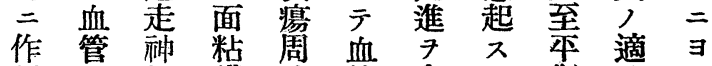
用性 經 朕邊管来 ル衡量 ル

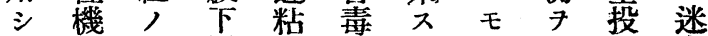
潰 轉ソ層膜七心゙, 保興走 瘍二レノ下スクトツが神 分近二出層夕、思八效經 向接 $\exists$ 血 $三$ 隨考當果聚 樑 $九$ 於 $ン$ 少 的三胃充方, 天。原二 傾 $x$ 壁血 ル運 $大^{(37)}$ 及 事 ル 對 向夕收中結 命掘条 7 シ フ 縮 等 締 二 桀 抑二三度 織 對 末(38)腺モル抗 制 依依三㵶 三 松卜甲モ的 七ルり㙕維一松七狀首三 ルナ惹 ス堆面黑(39) ス 腺肯作 モラ 起 ル 殖迷川夕機 少用 ノンサモ著走, 肙能 卜力ル, 思神如 $ン$, 得 思・ベアク經多多多无 考之キル回繁少, 閔シ, ス スピり 整初公鑑ク釋 ルロテ修調期前揱撼得

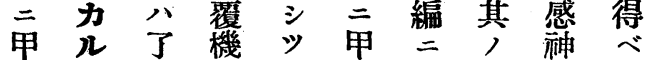

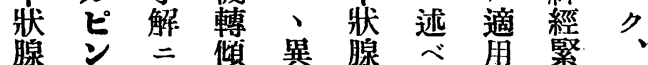
質粘手强清能 ル量菲氮菅 


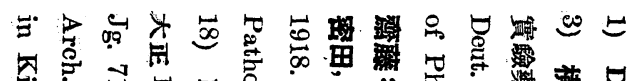

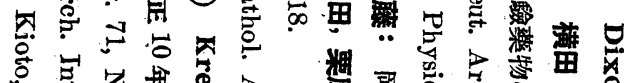

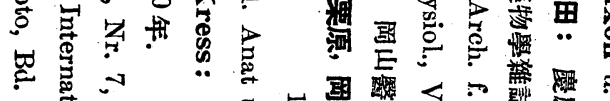

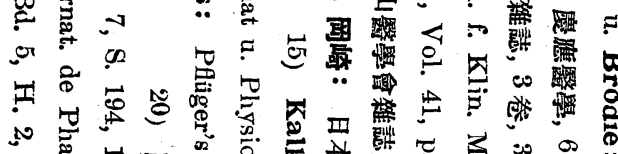

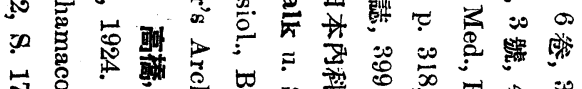

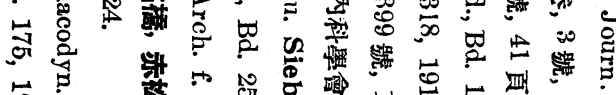

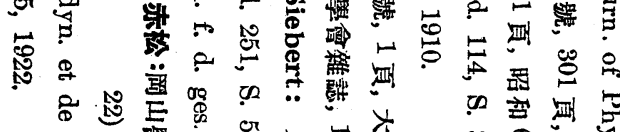

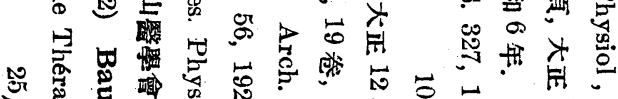

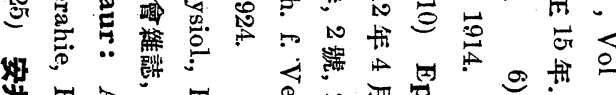

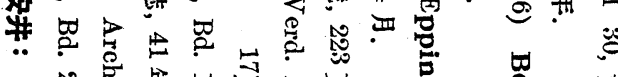

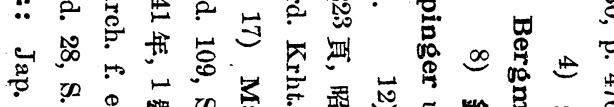

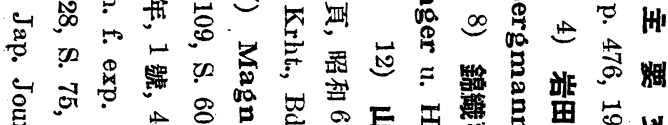

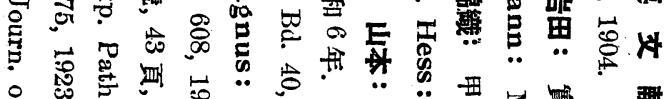

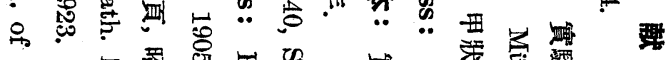

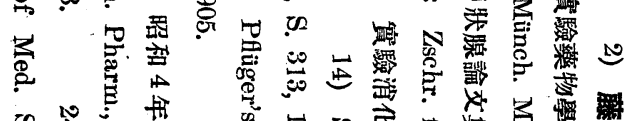
क.

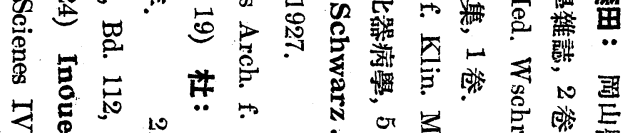

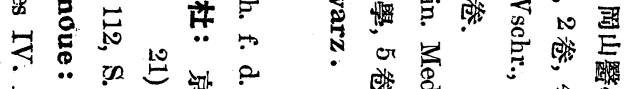

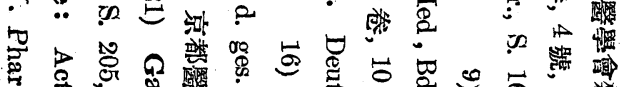
产 है ट

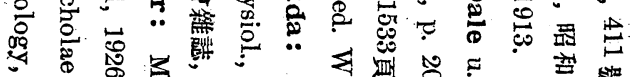
or

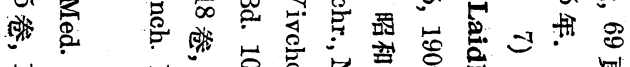

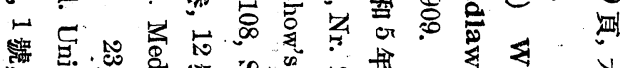

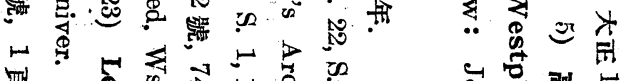

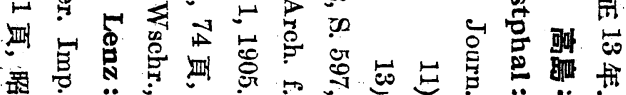

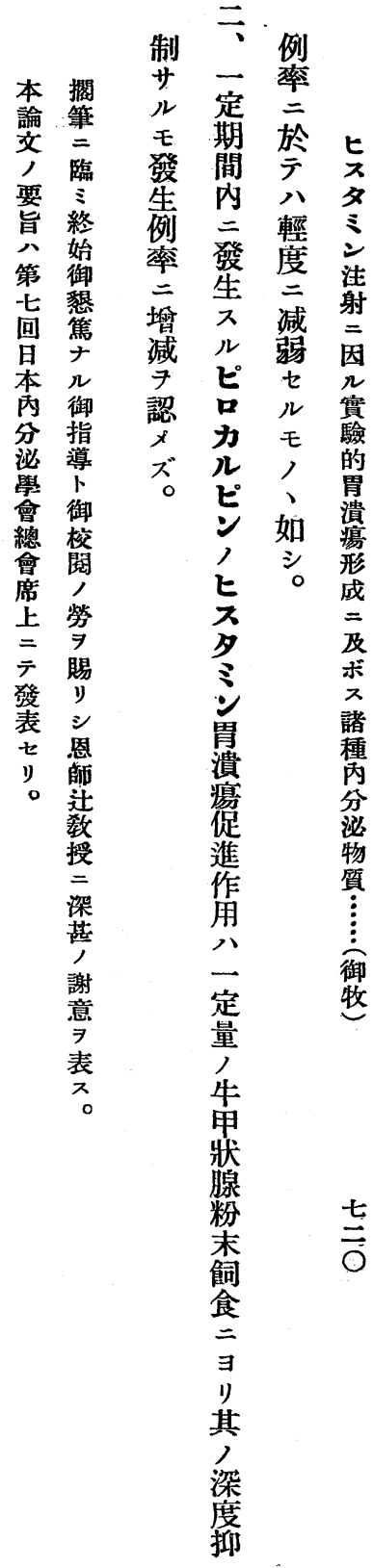




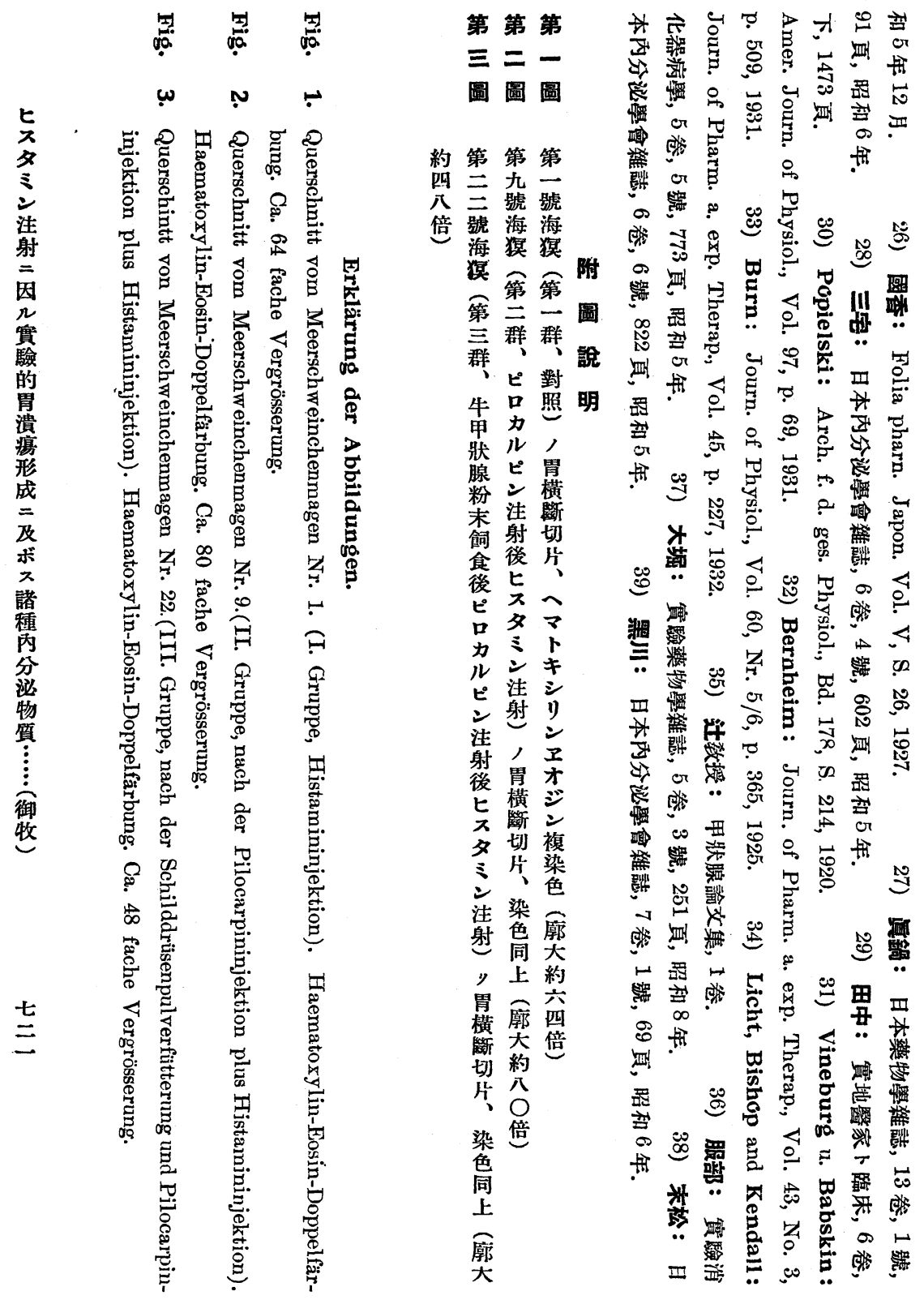


Fig. 1.

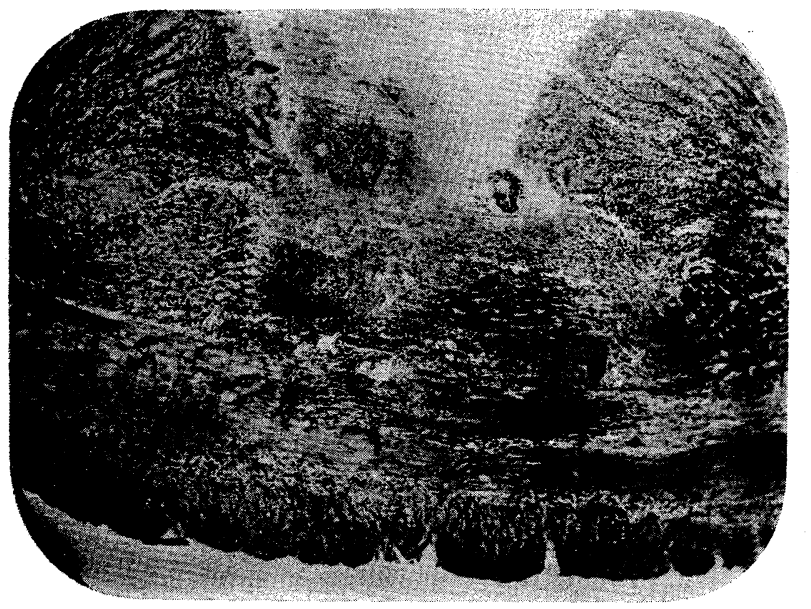

御

牧

論

文

附

圖

Fig. 2.

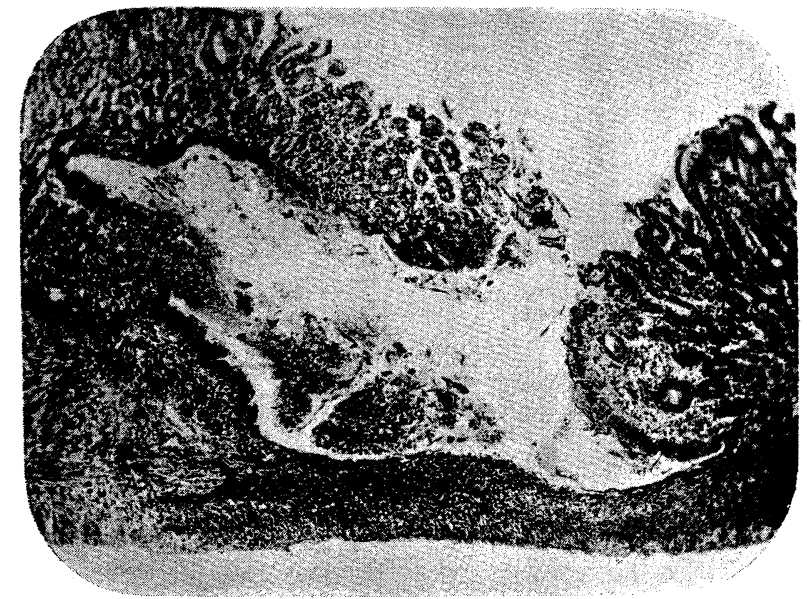

Fig. 3.

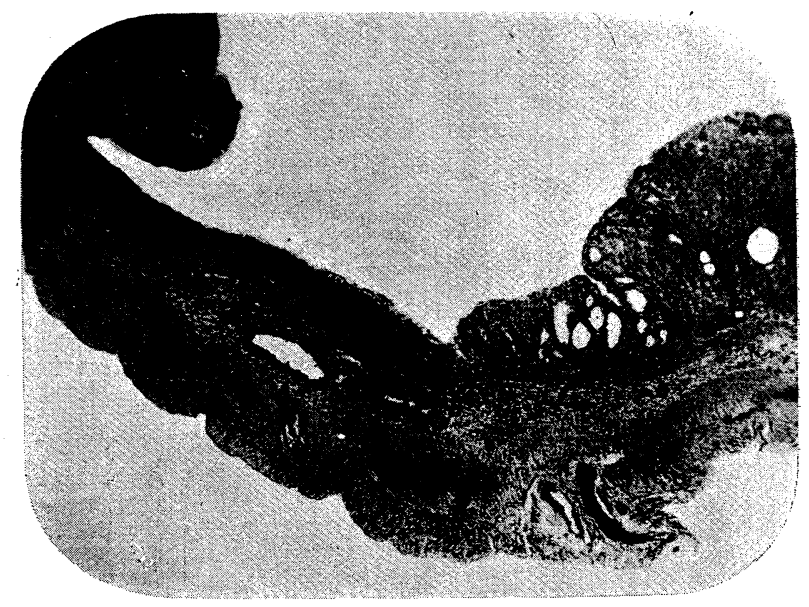


Epithelzellensubstang 7-8 Tage lang (3. Gruppe). Doch in der 1. u. 2. Gruppe wurde durch Aceton- bezw. Salzsäurealkoholextrakt dieser durch die Epithelzellensubstanzdarreichung sehr gesteigerte $\mathrm{N}$ Stoffwechsel viel rascher herabgesetzt als beim Kontrolltier. Diese Wirkung war stärker beim Aceton-als beim Salzsäurealkoholextrakt.

(Autoreferat)

Über den Einfluss endokriner Substanzen und anderer Arzneimittel auf die Entstehung des experimentell durch Histamininjektion erzeugten Magengeschwüres.

III. Mitt. Über den Einfluss von Pilocarpin und die Wirkung der Schilddrüse auf diesen Einfluss.

\author{
Von
}

Dr. S. Mimaki.

(Aus der I. Med. Klinik der Kaiserl. Univers. zu Kyoto in Japan. Director : Prof. Dr. K. Tsuji)

Um festzustellen, welchen Einfluss Pilocarpin auf die Entwicklung des Histamingeschwüres ausübt, und weiter, welche Wirkung die Schilddrüse auf diesen Einfluss hat, injizierte der Verfasser einer Gruppe von Meerschweinchen Histamin subkutan in derselben Menge und nach derselben Methode wie bei Gruppe 1 der I. Mitt. Eine andere Gruppe wurde in Untergruppen geteilt, bei denen den Tieren 7 Tage lang 10-20 Minuten vor jeder Histamininjektion (a) $0.2-0.4 \mathrm{mg}$, (b) $0.6 \mathrm{mg} 0.1 \%$ ige Pilocarpinum hydrochlọicumlösung pro $100 \mathrm{~g} \mathrm{~K}$. G. subkutan injiziert wurde.

Bei der dritten Gruppe wurden die Tiere zunächst 7 Tage lang mit Schilddrüsenpulver (jedes Tier erhielt als Gesamtmenge $0.03-0.04 \mathrm{~g}$ ) gefüttert und dann weiter wie die der Giuppe II behandelt. 
Die Resultate waren die folgenden :

1). Durch die subkutane Injektion einer bestimmten Menge Pilocarpinum hydrochloricum-lösung wurde die Tiefe des Histaminmagengeschwüres, das in einer bestimmten Zeit entsteht, gefördert, und es scheint dem Verfasser, dass bei der Pilocarpininjektion prozentual etwas weniger Geschwüre entstanden.

2 ). Durch die Fütterung mit einer bestimmten Menge Schilddrüsenpulver wurde diese obenbeschriebene Pilocarpinwirkung in der Tiefe des Geschwüres gehemmt, doch es entstanden prozentual ebensoviele Geschwüre wie mit Pilocarpininjektion allein.

(Autoreferat)

\section{Wirkung verschiedener Organextrakte der Meerschweinchen auf die durchströmte isolierte Kaninchenlunge.}

Von

Dr. I. Tominaga.

(Aus der I. Med. Klinik der Kaiserl. Univers. zu Kyoto in Japan. Direktor: Prof. Dr. K. Tsuji.)

Beim Studium des Wesens der blutdrucksenkenden Wirkung der Organextrakte fanden wir die interessante Tatsache, dass mehrere biologische Wirkungen der Organextrakte der sogenannten paradoxen gefässdilatatorischen Mittel, wie Histamin und Pepton, einander sehr ähnlich sind.

Der Verfasser untersuchte die Wirkung verschiedener Organextrakte (Lunge, Darm, Leber und Niere) der Meerschweinchen auf die isolierte, in einer Atmungsapparatur mit Lockscher Lösung durchströmte Kaninchenlunge und verglich diese Wirkung mit der früher von Miyake (Folia endocrinologica Japonica, Band VI, Heft VI, S. 48) und dem Verfasser (Folia endocrinologica Japonica, Band IX, Heft XI, S. 108) mitgeteilten charakteristischen Lungenwirkungen des Histamins und des. Peptons. 